\title{
A Review of Bioactive Glass/Natural Polymer Composites: State of the Art
}

\author{
Rachele Sergi, Devis Bellucci and Valeria Cannillo *(B) \\ Dipartimento di Ingegneria Enzo Ferrari, Università degli Studi di Modena e Reggio Emilia, Via P. Vivarelli 10, \\ 41125 Modena, Italy; rachele.sergi@unimore.it (R.S.); devis.bellucci@unimore.it (D.B.) \\ * Correspondence: valeria@unimore.it; Tel.: +39-059-205-6240
}

Received: 13 November 2020; Accepted: 4 December 2020; Published: 6 December 2020

check for updates

\begin{abstract}
Collagen, gelatin, silk fibroin, hyaluronic acid, chitosan, alginate, and cellulose are biocompatible and non-cytotoxic, being attractive natural polymers for medical devices for both soft and hard tissues. However, such natural polymers have low bioactivity and poor mechanical properties, which limit their applications. To tackle these drawbacks, collagen, gelatin, silk fibroin, hyaluronic acid, chitosan, alginate, and cellulose can be combined with bioactive glass (BG) nanoparticles and microparticles to produce composites. The incorporation of BGs improves the mechanical properties of the final system as well as its bioactivity and regenerative potential. Indeed, several studies have demonstrated that polymer/BG composites may improve angiogenesis, neo-vascularization, cells adhesion, and proliferation. This review presents the state of the art and future perspectives of collagen, gelatin, silk fibroin, hyaluronic acid, chitosan, alginate, and cellulose matrices combined with BG particles to develop composites such as scaffolds, injectable fillers, membranes, hydrogels, and coatings. Emphasis is devoted to the biological potentialities of these hybrid systems, which look rather promising toward a wide spectrum of applications.
\end{abstract}

Keywords: natural polymers; bioactive glasses; composites; mechanical properties; biological performance

\section{Introduction}

Over the past 40 years, life expectancy in industrialized countries has continued to rise thanks to many factors such as healthier nutrition, health care system and public health efforts, medical treatments, and more salubrious lifestyles [1,2]. However, this progress goes hand in hand with an increase of pathologies and work-related accidents such as spinal problems, arthritis, joint dysfunction, traumatic injuries, and lacerations [3,4]. Such diseases imply dramatic suffering for patients and might cause severe and long-term pain, work limitation, and disability. In this context, biomaterials' science can make an important contribution to medicine, thanks to the possibility to design increasingly advanced prostheses and implants to be used in several clinical applications to correct and improve irregularities and abnormalities (i.e., spinal rods, pacemaker, stent), to assist in recovery from injury (structural, pharmaceutical effects), and to replace body parts that lose function (total hip, heart). Therefore, new biomaterials with greater biological response, biocompatibility, and thermal and mechanical properties have been increasingly studied $[5,6]$.

Biomaterials, which should be biocompatible, intrinsically non-toxic, non-carcinogenic, and non-allergenic, can be classified as first generation, second generation, and third generation according to their response in the host. First-generation biomaterials had the aim to achieve a proper combination of mechanical and biological properties that correspond to those of the replaced tissue. Typically, these biomaterials do not cause or undergo chemical or biological changes in the host. On the contrary, second-generation biomaterials can promote a specific biological response on the biomaterials' surface. 
Therefore, second-generation biomaterials can stimulate the formation of new bone by inducing a controlled action and reaction mechanisms in a biological environment $[5,7]$. On the other hand, a specific response at the molecular level is promoted by third-generation biomaterials [8]. In fact, such devices can be gradually degraded and substituted by living host tissues.

Biomaterials may include ceramics, glasses, metals, and polymers with their specific properties $[9,10]$. Since polymers are the most versatile class of biomaterials, they have been extensively used in industrial applications such as farming, food sectors, pharmaceutical, and biomedical fields. Polymers are classified into synthetic and natural types: a large number of synthetic polymers are synthesized from petroleum oil through a series of chemical reactions, while natural polymers are extracted from animal waste or plants in nature [11-13]. Synthetic polymers can be classified as (i) hydrophobic, non-water absorbing materials (i.e., polyethylene (PE), polypropylene (PP), poly(methylmethacrylate) (PMMA)); (ii) more polar systems (i.e., copoly(lactic-glycolic acid) (PLGA)) (iii) water-swelling materials (i.e., poly (hydroxyethyl methacrylate) (PHEMA)); and (iv) water-soluble materials (i.e., poly (ethylene glycol) (PEG)). On contrary, natural polymers can be broadly categorized as (i) proteins such as collagen, gelatin, and silk fibroin; (ii) polysaccharides such as chitosan, hyaluronic acid, alginate, and cellulose; (iii) and polynucleotides (DNA, RNA) [12,14].

Regardless of whether they are synthetic or natural, small repeating units constitute the long chain molecule of polymers [12,15]. In synthetic polymers, the small units (i.e., monomers) and the polymerization process influence the characteristic of the final system, such as its crystallinity, molecular weight, and melting temperature $[16,17]$.

Some synthetic polymers lose their integrity once implanted in the body; the degradation kinetic varies from a few weeks to a few years depending on the polymers' chemical composition and on the surrounding physiological environment [15]. Their gradual degradation begins when the surface of the system starts to absorb components such as water, proteins, and ions from the surrounding environment [15]. Of course, the degradation products released from synthetic polymers should be non-toxic for the host organism. However, as this does not always happen, the efforts of many researchers have been focused on natural polymers, which usually degrade into soluble, non-toxic chemical species [11]. These chemical species are recognizable and metabolized by the body [18], being body-friendly species. Furthermore, synthetic polymers have been partially replaced by natural ones because the latter do not lack in cells recognition sequences $[19,20]$, and the stimulation of a chronic immunological reaction is avoided [21]. Furthermore, natural polymers show more similarity to the extracellular matrix (ECM, network of biomacromolecules including glycosaminoglycans, which are polysaccharides and fibrous proteins such as collagen, laminin, elastin, and fibronectin [12]), being readily recognizable by the body compared to the synthetic ones. Such similarity to ECM could be summarized as a suspension of macromolecules that support everything from local tissue growth to the maintenance of an entire organ. In this context, since ECM provides structural support and modulates the activity of growth factors, it represents one of the main footprints for designing biomaterials [22]. Thus, the ideal biomaterial for tissue engineering applications should be able to recreate the dynamic biochemical, structural, and mechanical properties of the naturally occurring ECM.

However, despite these positive aspects, natural polymers show lower stability in terms of physical and mechanical properties compared to synthetic ones [11]. Moreover, natural polymers suffer some limitations due to their solubility and industrially acceptable processability: (i) variation in the final properties of polymer due to their source, (ii) some contamination caused by the presence of microbes, (iii) uncontrolled water uptake, and (iv) an unpredictable degradation route. Furthermore, since most natural polymers are water-soluble, various crosslinking methods to control their structure, water uptake, and degradation in aqueous environment have been developed [23,24].

Generally, natural polymers have been combined with one another to improve workability; in addition, natural polymers are typically combined with ceramics fillers (i.e., ceramics, glass-ceramics, bioactive glasses) to reinforce the structure of the final system and, thus, to produce composites with a better mechanical performance $[25,26]$. It is known that bioactive glasses (BGs), and especially 
the "gold standard" 45S5 Bioglass ${ }^{\circledR}$ [27], have been widely used in several clinical applications in regenerative medicine, tissue engineering, and dentistry [27-31] by virtue of the ability of bonding to bone. The bonding ability to bone of BGs is mediated by the formation of bone-like hydroxy carbonate apatite (HCA) on the surface of BGs once in contact with physiological fluids. The structure and chemistry of HCA is similar to natural apatite, which is the mineral phase of bones; thus, the deposition of HCA on the surface of biomaterials is typically considered one of the initial steps that lead to the formation of a stable bond at the implant/tissue interface [32,33]. Indeed, the rapid physiochemical reciprocal influence between the surface of biomaterials and the surrounding environment with the silica layer and HCA layer formation represent the first step to the success of an implant. Additionally, $45 S 5$ Bioglass ${ }^{\circledR}$ is osteoinductive and able to bond to both soft and hard tissues [34]. However, in recent years, many BGs have been developed, especially those containing the so-called therapeutic ions such as strontium and magnesium [35-47]. The addition of specific and therapeutic ions that are released during bioactive glass degradation $[48,49]$ aims at enhancing specific cellular response in the host, favoring regenerative processes. Special attention has been paid to the development of sodium containing BGs and/or borate bioactive glasses to improve reactivity in terms of bioactivity and biological response. On the other hand, $\mathrm{Cu}, \mathrm{Zn}$, and $\mathrm{Ag}$ ions have been incorporated to achieve bioactive glasses with antibacterial properties [50-54]. For these reasons, BGs can be added to natural polymers, which behave as a matrix in order to obtain innovative composites (i) with improved bioactive behavior [55], (ii) with the ability to release therapeutic ions which stimulate a specific molecular response, (iii) and/or with the capability to release alkali ions that counteract the acid by-products from polymers degradation.

This review presents the state of the art about the production of composites based on BGs combined with natural polymers: (i) proteins such as collagen, gelatin, silk fibroin, and (ii) polysaccharides such as hyaluronic acid, chitosan, alginate, and cellulose, which are widely used as biomaterials and look particularly promising for several clinical applications. A specific emphasis is given here on the biological performance of such innovative systems, which could open interesting scenarios in the field of biomaterials. Figure 1 schematizes the natural polymers that can be combined with bioactive glasses to fabricate advanced composites, as described in the following.

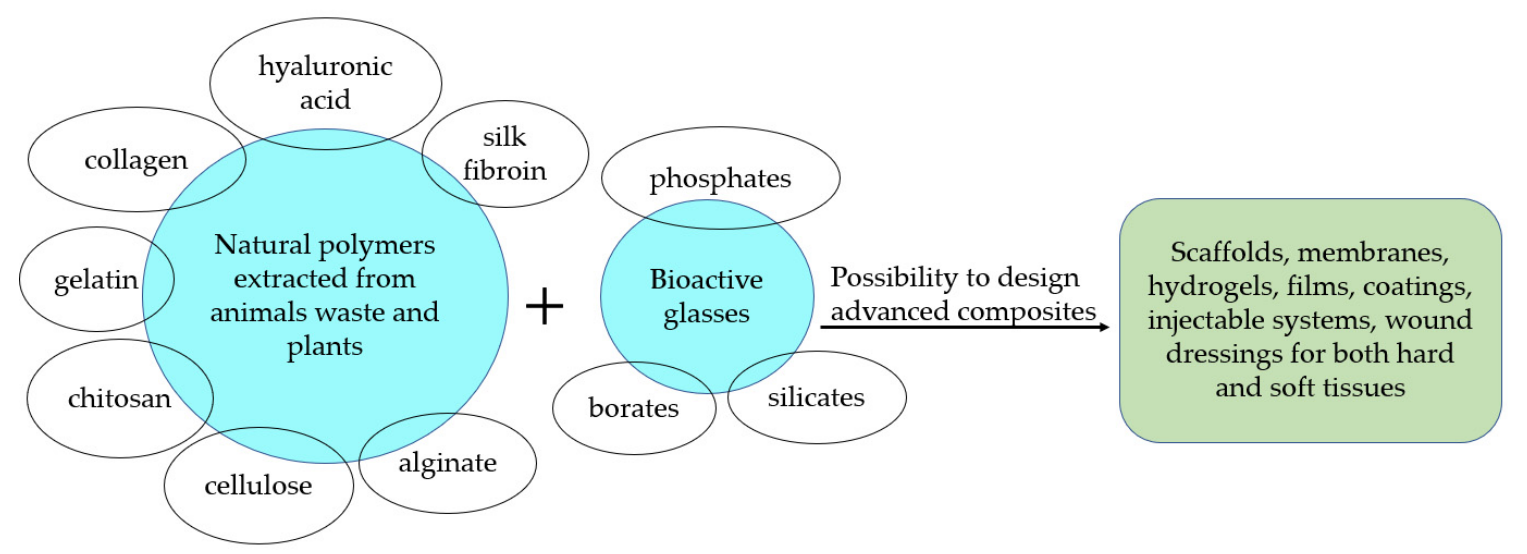

Figure 1. Schematic graph of natural polymers combined with bioactive glasses to fabricate advanced composites.

\section{Natural Polymers: Proteins}

Proteins are assemblies of various amino acids and are monodisperse [12]; various moieties can attach on the amino acid side chain, leading to different physical and biochemical properties of the original protein. Proteins have potential limitations such as immunogenicity as well as batch-to-batch differences consequent to purification processes. Furthermore, proteins materials are generally harvested from animal sources, complicating translation to a clinical setting [56]. Proteins such as collagen, elastin, silk fibroin, and gelatin have been studied as potential scaffolds for 
tissue applications [12]. Such protein-based materials are useful in sutures, drug delivery vehicles, etc. Proteins-based materials as well as biomaterials in general have to offer tunable degradability providing control over the sequestration and delivery of specific bioactive factors to improve and guide healing and regeneration over a long period. Collagen, gelatin, and silk fibroin with the incorporation of bioactive glasses are considered below.

\subsection{Collagen/Bioactive Glass Composites}

Collagen is a protein that forms the structural basis for much of the extracellular matrix (ECM) of our tissues; therefore, it is the most studied polymer among natural ones.

In the human body, among several types of collagen, types I-IV are the most common [12]. In bone, type I collagen is combined with hydroxycarbonate apatite nanocrystals to create a bio-composite tissue that is highly organized from the nano to macroscopic length scale [57]. In particular, fibers of type I collagen promote cell adhesion and proliferation: cells typically adhere on the collagen surface by integrin $\alpha_{2} \beta_{1}$, which is a primary adhesion receptor used by osteoblast-like cells to bond to the collagen surface (i.e., the substrate), favoring cell-cell interaction and cell-matrix binding $[15,58]$.

Furthermore, collagen stimulates the differentiation of stromal cells of bone marrow [59]. Therefore, as the key component of the ECM, collagen induces bone regeneration and remodeling $[60,61]$ by stimulating bone cells' metabolic activity [62]. Collagen is suitable for different biomedical applications because it can mimic the mineralization as well as the mechanical and biological properties of osteoid [63]. In addition, its hydrophilic properties, hemostatic capability [12], high processability, and versatility in terms of physical forms give the possibility of using collagen for various products such as injectable gels, films, meshes, and fibers [64-67], bone and cartilage repair constructs [68,69], skin grafts [70], and wound dressings [71,72].

Despite its versatile form, collagen suffers from a high degradation rate and low mechanical properties (i.e., mechanical strength and stiffness), which can be enhanced by adding a specific reinforcing phase [12,73]. In this context, bioactive glasses (BGs) look particularly interesting as a second phase in a collagen-based composite to improve the mechanical properties of the system as well as the biological ones. It has been reported that bioglass nanofibers added to collagen can reduce infections and induce skin regeneration, thus making the final composite more suitable for clinical uses [73]. Therefore, the appropriate combination of bioactive glasses and collagen leads to biomedical devices that mimic the composition of natural bone. In particular, artificial scaffolds have been developed to solve the limitations of autografts, i.e., limited resources, additional pain, and the morbidity of donor sites [74]. The microporous structure of artificial scaffolds has high porosity and interconnected pores, which permit the spreading and growth of cells, while allowing the flow of nutrients and growth factors (GFs) toward cells and waste products from cells to the surrounding environment $[75,76]$. This microporous interconnectivity aids cells in multiplying and differentiating into the mature type of tissues [77].

However, an adequate balance between the porosity and bulk structure should be achieved to avoid the failure of structure. In this regard, BGs incorporated in collagen scaffolds resulted in improving compression and elastic modulus compared to pure collagen scaffolds [78]. Furthermore, BGs improved biological responsiveness as well [78]. As mentioned in the introduction, the incorporation of specific ions into the BGs composition enhances the specific cellular response in the host. Indeed, the biological responsiveness and performance of collagen/BGs composites is also associated with bioactive glasses composition [40,79].

The ionic sources such as $\mathrm{Ca}, \mathrm{Si}$, and $\mathrm{P}$ from bioactive glasses accelerate the precipitation of mineral phase on the surface of scaffolds. The hydroxy carbonate apatite (HCA) was detected on collagen/bioactive glass scaffolds 3 days after soaking in Simulated Body Fluid (SBF) solution $[79,80]$. The mineralization during immersion in SBF affects the mechanical properties of collagen/45S5 scaffolds, resulting in a transition from a soft to hard tissue with higher resistance to compressive stress [80]. Additionally, the mineralization involves the gradual degradation of BGs, inducing partial degradation 
of the composite. The degradation rate of composites should be equal to the rate of formation of new tissues [81]. The BGs degradation results in ion releasing, which stimulate the bioactivity as well as cells adhesion and proliferation on collagen/bioactive glass scaffolds compared to pure collagen scaffolds $[79,80,82]$. Indeed, it is known that the ions released by BGs regulate the gene expression and differentiation of cells to progenitor or stem cells as reported in $[83,84]$. Once in contact with human body, the typical ions in BGs composition (i.e., Ca, Si, P) influence bone metabolism and angiogenesis. For instance, the $\mathrm{Si}$ ion is essential for the metabolic process and for the formation and calcification of bone tissue $[85,86]$; the Ca ion enhances osteoblast proliferation, differentiation, and extracellular matrix (ECM) differentiation [87-89]; the P ion stimulates the expression of matrix protein, which is a key regulation of bone formation $[90,91]$. Therefore, the introduction of BGs, which release ions directly involved in tissue growth, in particular bone growth, could improve the final properties of collagen/BGs composites compared to collagen scaffolds only [92].

Although scaffolds have acquired extra importance in the regeneration and repair of damaged tissues [93-95], to overcome the limit of their rigid structure, injectable systems for small and irregular defects of both hard and soft tissues have been developed [40,82,96-98]. Collagen/BGs $\left(\mathrm{CaO}-\mathrm{P}_{2} \mathrm{O}_{5}-\mathrm{SiO}_{2}\right)$ hydrogels developed by Eglin et al. [96] showed an HCA layer after immersion in SBF solution, confirming that the presence of bioactive glass particles enhances the bioactivity of collagen. The chemical interaction between collagen molecules and bioactive glass nanoparticles should enable a more chemically stable network $[99,100]$, avoiding the faster and total degradation of BGs phase with respect to the degradation of the collagen phase.

Furthermore, the amount of bioactive glass particles into biomedical devices should not exert an excessive inflammatory response during degradation. The inflammatory response could cause an anti-angiogenesis effect, leading to a failure of collagen/BGs composites [97]. For these reasons, the amount of BGs in collagen and the degradation rate of the composite could be controlled by tailoring BGs composition and relative volume fraction, for example. To further control the degradation rate of BG, an improvement of the chemical interaction between collagen and bioactive glass (binary composition of $85 \% \mathrm{SiO}_{2}-15 \% \mathrm{CaO}$ in $\mathrm{mol} \%$ ) should be reached [98]. In this regard, the amination process aims at forming a strong chemical link between the additional amino group of bioactive glasses and the carboxyl group of collagen [98]. This process resulted in a preservation of the original shape and in improving mechanical properties of collagen $/ 85 \% \mathrm{SiO}_{2}-15 \% \mathrm{CaO}$ hydrogels [98].

Improved mechanical properties were measured also for collagen/bioactive glass $(\mathrm{BG}, \mathrm{Si} / \mathrm{Ca} / \mathrm{P}=$ 80:15:5) nanofibers developed by the electrospinning technique [101]. Furthermore, collagen/bioactive glass nanofibers promoted the adhesion and proliferation of human dermal fibroblasts (HDFs) cells inducing the secretion of type I collagen (COL-I) and vascular endothelial growth factor (VEGF) [101]. It has been demonstrated that COL-I forms most of the connective tissue in wound healing [102,103] and VEGF stimulates angiogenesis, which could be related to Si ions from BGs, as such ions have been shown to enhance angiogenesis $[29,104,105]$. The increased angiogenic capability of collagen/bioactive glass composites was coincident with a weaker inflammatory response compared to that of collagen films [101]. By tailoring the amount and composition of bioactive glasses as well as the morphological characteristics of composites, a specific molecular response and improved angiogenesis can be achieved [106,107]. Composites with good mechanical properties and improved biological performances could provide better 3D condition for progenitor or stems cells [108-110].

Table 1 summarizes collagen/bioactive glass composites. 
Table 1. Summary of collagen/bioactive glass composites for various biomedical applications.

\begin{tabular}{|c|c|c|c|c|}
\hline Bioactive Glass & Technique & Composites' Characteristics & Applications & Ref. \\
\hline $\begin{array}{c}\text { BGMS10 } \\
\left(2.3 \mathrm{Na}_{2} \mathrm{O}-2.3 \mathrm{~K}_{2} \mathrm{O}-\right. \\
25.6 \mathrm{CaO}-10.0 \mathrm{MgO}-10.0 \\
\mathrm{SrO}-2.6 \mathrm{P}_{2} \mathrm{O}_{5}-47.2 \\
\left.\mathrm{SiO}_{2} \mathrm{~mol}^{2}\right)\end{array}$ & $\begin{array}{l}\text { Manually } \\
\text { mixing }\end{array}$ & $\begin{array}{l}\text { Non-cytotoxic; putties containing } \\
\text { bioactive glass enhanced cell } \\
\text { proliferation }\end{array}$ & $\begin{array}{l}\text { Dentistry and } \\
\text { reconstructive } \\
\text { surgery }\end{array}$ & [40] \\
\hline $\begin{array}{c}65 \mathrm{SiO}_{2}-30 \mathrm{CaO}-5 \mathrm{P}_{2} \mathrm{O}_{5} \\
w \mathrm{t} \%\end{array}$ & $\begin{array}{l}\text { Slurry-dipping } \\
\text { technique }\end{array}$ & $\begin{array}{c}\text { Porosity of } 81 \pm 4.6 \% \text { and pore size of } \\
40-200 \mu \mathrm{m} \text {; water adsorption } \\
52.26 \pm 11.37 \% \text {; compression strength } \\
5.80 \pm 1.60 \mathrm{MPa} \text {; elastic modulus } \\
0.35 \pm 0.10 \mathrm{GPa} \text {; flexure strength } \\
1.90 \pm 0.15 \mathrm{MPa} \text {; flexure modulus } \\
27.90 \pm 1.32 \mathrm{MPa} \text {; tensile strength } \\
3.56 \pm 0.22 \mathrm{MPa} \text {; tensile modulus } \\
82.00 \pm 17.40 \mathrm{MPa} \text {. The mechanical } \\
\text { properties well-matched with the } \\
\text { mechanical properties of trabecular } \\
\text { bones; good biocompatibility }\end{array}$ & $\begin{array}{l}\text { Scaffolds for hard } \\
\text { tissue }\end{array}$ & [78] \\
\hline $58 \mathrm{~S}, 70 \mathrm{~S}$ & $\begin{array}{l}\text { Freeze-drying } \\
\text { and } \\
\text { lyophilization } \\
\text { technique }\end{array}$ & $\begin{array}{l}\text { Porosity } 87-88 \% \text {; density } \\
0.0015-0.0016 \mathrm{~g} / \mathrm{cm}^{3} \text {. Induced bone } \\
\text { mineral-like phase, signs of in vitro } \\
\text { bone bioactivity }\end{array}$ & $\begin{array}{l}\text { Scaffolds for hard } \\
\text { tissue }\end{array}$ & [79] \\
\hline $45 \mathrm{S5}$ (nanoparticles) & $\begin{array}{l}\text { Plastic } \\
\text { compression } \\
\text { technique }\end{array}$ & $\begin{array}{l}\text { Good cell viability, high ALP activity, } \\
\text { crystalline carbonated hydroxyl } \\
\text { apatite growth }\end{array}$ & $\begin{array}{c}\text { Scaffolds for } \\
\text { potential bone } \\
\text { tissue engineering }\end{array}$ & [80] \\
\hline $58 \mathrm{SiO}_{2}-38 \mathrm{CaO}-4 \mathrm{P}_{2} \mathrm{O}_{5}$ & $\begin{array}{l}\text { Freeze-drying } \\
\text { technique }\end{array}$ & $\begin{array}{l}\text { Average thickness } 181 \mu \mathrm{m} \text {. Active } \\
\text { induction of apatite minerals; } \\
\text { significantly high ALP levels }\end{array}$ & $\begin{array}{l}\text { Membranes and } \\
\text { scaffolds for bone } \\
\text { regeneration }\end{array}$ & [82] \\
\hline $\begin{array}{l}\mathrm{CaO}-\mathrm{P}_{2} \mathrm{O}_{5}-\mathrm{SiO}_{2} \text { or } \\
\text { silica particles }\end{array}$ & Mixing solution & In vitro osteoconductivity properties & $\begin{array}{l}\text { Hydrogels for bone } \\
\text { repair and tissue } \\
\text { engineering }\end{array}$ & [96] \\
\hline $45 S 5$ & $\begin{array}{l}\text { Compression } \\
\text { molding }\end{array}$ & Early angiogenic response & $\begin{array}{l}\text { Films for tissue } \\
\text { engineering and } \\
\text { regenerative } \\
\text { medicine }\end{array}$ & [97] \\
\hline $\begin{array}{c}\text { Mesoporous bioactive } \\
\text { glass nanoparticles } \\
\text { mBGn } \\
\left(85 \mathrm{SiO}_{2}-15 \mathrm{CaO}\right. \\
\mathrm{mol} \%)\end{array}$ & Solvent casting & $\begin{array}{l}\text { Improved chemical stability, reduced } \\
\text { hydrolytic and enzymatic } \\
\text { degradation, and increased resistance } \\
\text { to loading and stiffness. Storage } \\
\text { modulus (E') of collagen } \\
(\mathrm{Col})=75 \mathrm{kPa}, \mathrm{E}^{\prime} \text { of } \\
\text { collagen } / \text { bioactive glass }(\mathrm{Col}-\mathrm{mBGn}) \\
=130-160 \mathrm{kPa} \text { and } \mathrm{E}^{\prime} \mathrm{Col}-\mathrm{mBGn} \\
(\text { Aminated })=150-280 \mathrm{kPa}\end{array}$ & $\begin{array}{l}\text { Hydrogel for hard } \\
\text { tissue engineering }\end{array}$ & [98] \\
\hline $\begin{array}{c}\mathrm{Si} / \mathrm{Ca} / \mathrm{P}=80: 15: 5 \\
\mathrm{~mol} \%\end{array}$ & Electrospinning & $\begin{array}{c}\text { Improved tensile strength, } \\
\text { promotion the secretion of type I } \\
\text { collagen (COL-I) and vascular } \\
\text { endothelial growth factor (VEGF) in } \\
\text { human dermal fibroblast (HDFs), } \\
\text { in vivo: skin regeneration in the } \\
\text { wound area }\end{array}$ & $\begin{array}{l}\text { Skin wound } \\
\text { dressing }\end{array}$ & [101] \\
\hline
\end{tabular}

\subsection{Gelatin/Bioactive Glass Composites}

Gelatin is a translucent natural nontoxic colorless and brittle natural polymer. It is obtained from collagen that is thermally denaturized or physically/chemically degraded to break its natural triple helix. 
The manufacturing process of gelatin consists of (i) the pre-treatment of raw materials for the main extraction step; (ii) the main extraction step, which is the hydrolyzation of collagen into gelatin, and (iii) the final steps to eliminate water from gelatin solution to obtain dried, blended, and ground final gelatin. Being the denaturized form of collagen, gelatin can overcome the concerns about causing an immune response and a transmission of pathogens related to collagen [12].

Furthermore, the unique sequences of amino acids (i.e., glycine, proline, and hydroxyproline) of gelatin influence its biocompatibility and enhance cellular adhesion and proliferation. Therefore, the biocompatibility, biodegradability, and very low antigenicity of gelatin make it appropriate for both hard and soft tissue applications.

Unfortunately, the fast degradation rate in physiological fluids and poor mechanical properties of gelatin limit its application [12]. However, these deficiencies can be mitigated by stabilizing gelatin in a physiological environment using crosslinking agents (i.e., glutaraldehyde and genipin). Since glutaraldehyde could induce cytotoxicity effects, methacrylic anhydride (i.e., a chemical crosslinker) has raised interest due to its inherent biocompatibility, biodegradability, and simplicity in synthesis [111]. Gelatin methacryloyl (GelMA) was produced by adding to type A gelatin (in PBS) the methacrylic anhydride under stirring, as described in detail in [111]. However, gelatin methacryloyl as pure gelatin showed lower ability in promoting tissue regeneration in the absence of bioactive materials. In fact, the development and fabrication of composites for biomedical devices using biodegradable polymers and bioactive materials is currently an open challenge.

In the last decades, bone tissue engineering has become a promising approach to channel this challenge in which composites, bioactive materials, cells, and signaling biomacromolecules could be combined to achieve tissue regeneration.

In this regard, the delivery of cells using carriers (i.e., porous scaffolds) has been shown to be a more efficient method compared to the direct administration of cells in situ. The incorporation of endothelial cells in gelatin/bioactive glass scaffolds further enhanced bone regeneration by improving vascularity compared to simple gelatin/bioactive glass scaffolds [112]. In addition, a novel and high impact gelatin/bioactive glass $\left(64 \mathrm{SiO}_{2}-5 \mathrm{P}_{2} \mathrm{O}_{5}-31 \mathrm{CaO}\right.$ mol\%) scaffold, seeded with bone marrow mesenchymal stem cells (BM-MSCs) delivering bone morphogenetic protein-7 (BMP-7), exhibited a successful combination to enhance osteogenesis in bone defects [113]. An appropriate bonding between BM-MSCs/scaffolds and the host bone was related to the capability of bioactive glasses to form bonds with calcified tissues [113].

Indeed, bioactive glasses (BGs) are well known to be both osteoconductive and osteoinductive as well as biocompatible and highly bioactive. Unfortunately, BGs are brittle and exhibit poor mechanical properties, which limits their use in load-bearing applications. Thus, bioactive glasses incorporation into gelatin matrices to fabricate composites represent a feasible solution.

The chemical bonding reaction between the nanoparticles of bioactive glass $\left(\mathrm{nBG}, 64 \mathrm{SiO}_{2}-5 \mathrm{P}_{2} \mathrm{O}_{5}-31 \mathrm{CaO}\right.$ $\mathrm{mol} \%$ ) and gelatin is characterized by three major steps as reported elsewhere [114-116]: (i) a critical reaction between $\mathrm{Ca}^{2+}$ ions of $n B G$ and gelatin molecules; (ii) the $\mathrm{Ca}^{2+}$ ions complexing with gelatin molecules, which are assembled with $\mathrm{PO}_{4}{ }^{3-}$ ions; and (iii) the $-\mathrm{COOH}$ and $-\mathrm{NH}_{2}$ groups in the gelatin molecule form chemical bonds with the $\mathrm{P}-\mathrm{O}$ and $\mathrm{O}-\mathrm{H}$ groups of $\mathrm{nBG}$, resulting in a gelatin layer strongly attached to the surface of nBG.

Gelatin/bioactive glass $\left(64 \mathrm{SiO}_{2}-5 \mathrm{P}_{2} \mathrm{O}_{5}-31 \mathrm{CaO} \mathrm{mol} \%\right)$ scaffolds developed for bone tissue applications showed improved mechanical properties compared to gelatin scaffolds and human osteoblast-like cells (SaOS-2) cultured on gelatin/bioactive glass $\left(64 \mathrm{SiO}_{2}-5 \mathrm{P}_{2} \mathrm{O}_{5}-31 \mathrm{CaO} \mathrm{mol} \%\right)$ scaffolds were well attached to the pores of scaffolds, as confirmed by their numerous lamellipodia and filopodia [114-116]. The SaOS-2 can be used to study mechanisms that involve the late osteoblastic differentiation stage in human cells because of SaOS-2's capacity to deposit a mineralization-competent extracellular matrix (ECM). In addition, the formation of a hydroxy carbonate apatite layer on the biomaterials' surface represents one of the necessary requisites to bond with living bone. By incorporating BGs into gelatin matrices, the mineralization was supported compared to pure 
gelatin composites [116-119]. The topography, porosity, and surface of scaffolds contributed to a successful interaction with tissues as well as the incorporation of bioactive glasses.

High porous 3D dimensionally interconnected bioactive glass/gelatin composite scaffolds using a direct foaming process were developed [120]. This technique involves little or no organic solvents or hazardous chemicals being an appropriate alternative to conventional techniques used to fabricate synthetic polymer scaffolds and gelatin/BG scaffolds.

Another alternative technique to fabricate scaffolds with a grid-like microstructure was developed by Gao et al. [121]. The solid free form fabrication (SFF) method offered high control on scaffolds structure using a computer-aided design and robotic deposition [121]. Porous 3D gelatin/bioactive glass $\left(70 \mathrm{SiO}_{2}-25 \mathrm{CaO}-5 \mathrm{P}_{2} \mathrm{O}_{5} \mathrm{~mol} \%\right)$ scaffolds with high ability to form mineralized bone nodules by combined sol-gel and robocasting technique were developed [121]. On the other hand, the microsphere leaching technique using polymethylmethacrylate (PMMA) as a porogen agent was used to control the porosity of scaffolds [122]. The particle size of the sacrificial polymer spheres determines the porosity; therefore, a well-controlled and open porosity can be obtained by tailoring the size of particles [122]. Furthermore, PMMA can be easily dissolved in acetone, preserving the composite matrix.

During the fabrication of composites containing bioactive glasses, particular attention should be paid to maintaining the bioactive glass composition unchanged. Indeed, the uncontrolled leaching of alkali and alkaline-earth elements alters the property of BGs. The rate of degradation could be partially controlled by tailoring the BGs composition, which is also responsible for a wide range of biological and chemical responses in the host.

In this regard, the incorporation of Sr-doped bioactive glass into gelatin matrix was shown to enhance cell infiltration and neovascularization compared to scaffolds containing bioactive glasses without $\mathrm{SrO}$ [123]. The releasing of ions exhibited beneficial effects on bone formation at both cellular and tissue levels [123]. On the other hand, an $\mathrm{Mg}$ - Zn doped bioactive glass $\left(\mathrm{SiO}_{2}-\mathrm{CaO}-\mathrm{P}_{2} \mathrm{O}_{5}-\mathrm{MgO}-\mathrm{ZnO}\right)$ was added to the gelatin matrix to fabricate composite scaffolds for bone tissue engineering [124], aiming at stimulating cell growth and proliferation. $\mathrm{Mg}$ enhances the expression of collagen I and alkaline phosphatase (ALP) activity [37]. Zinc is involved in protein synthesis and is fundamental for the replication of DNA; it is a cofactor for enzymes, and it is engaged during bone cell growth, development, and differentiation [124]. For this reason, $\mathrm{ZnO}$ whiskers were added to gelatin/BGs scaffolds to improve cells proliferation; the addition of $\mathrm{ZnO}$ whiskers increased rat mesenchymal stem cells (rMSCs) proliferation [125]. Additionally, $\mathrm{ZnO}$ whiskers showed antibacterial properties that were favorable for obtaining multifunctional gelatin/BG composite scaffolds with antimicrobial activity [125]. Implanted devices could enhance the chance of infections causing implant failure, hospitalization, and sometime mortality of patients. Therefore, composites with antimicrobial properties would be highly desired. In this regard, a simple and "green" method was used to synthesize in situ silver nanoparticles in gelatin (i.e., a natural reducing and stabilizing agent) by reduction under heating [126]. The incorporation of BGs and silver nanoparticles enhanced human mesenchymal stem cells (hMSC) viability compared to gelatin scaffolds and increased the antibacterial effect of scaffolds with increasing silver nanoparticles [126]. Furthermore, $\mathrm{Cu}-\mathrm{BGN}\left(95 \mathrm{SiO}_{2}-2.5 \mathrm{CaO}-2.5 \mathrm{CuO} \mathrm{mol} \%\right) / g$ elatin coatings were used to successfully coat bioactive glass scaffolds introducing antibacterial properties without compromising the highly interconnected and porous structure of scaffolds [127].

It is worth noting that the concentration of bioactive glass particles in gelatin matrices should be carefully controlled to obtain desired improvements in terms of mechanical and biological properties and antibacterial effects.

Table 2 summarizes gelatin/bioactive glass composites. 
Table 2. Summary of gelatin/bioactive glass composites for various biomedical applications.

\begin{tabular}{|c|c|c|c|c|}
\hline Bioactive Glass & Technique & Composites' Characteristics & Applications & Ref. \\
\hline $40 \mathrm{SiO}_{2}-45 \mathrm{CaO}-15 \mathrm{P}_{2} \mathrm{O}_{5}$ & $\begin{array}{l}\text { Sequential physical } \\
\text { and chemical } \\
\text { crosslinking } \\
\text { (gelation + UV) } \\
\text { approach }\end{array}$ & $\begin{array}{c}\text { Average pore size }=90-200 \mu \mathrm{m} . \\
\text { Compressive modulus: "regular" } \\
\text { composites hydrogels }(0,2.5,5 \text { and } 10 \% \\
\text { w/v BG) }=54.1,51.2,50.2,46.0 \mathrm{kPa} ; \\
\text { "enhanced" composite hydrogels were } \\
\text { approximately 4.4-, 3.8-, 3.5-and 3.3-folds } \\
\text { greater than those of "regular" } \\
\text { composites hydrogels at } 0 \text { to } 10 \% \text { w/v BG. } \\
\text { High apatite forming ability. Highly } \\
\text { biocompatible; enhanced ALP activity }\end{array}$ & $\begin{array}{l}\text { Hydrogels for } \\
\text { bone } \\
\text { regeneration }\end{array}$ & [111] \\
\hline $64 S$ & $\begin{array}{l}\text { Layer solvent } \\
\text { casting combined } \\
\text { with freeze-drying } \\
\text { and lamination } \\
\text { techniques }\end{array}$ & $\begin{array}{l}\text { Porosity }=85 \% \text {; average pore size }= \\
200-500 \mu \mathrm{m} . \text { No cytotoxic effect on the } \\
\text { cell survival and proliferation in vitro; } \\
\text { bone regeneration in vivo }\end{array}$ & $\begin{array}{l}\text { Scaffolds for } \\
\text { tissue-engineered } \\
\text { bone defects }\end{array}$ & [112] \\
\hline $\begin{array}{c}64 \mathrm{SiO}_{2}-5 \mathrm{P}_{2} \mathrm{O}_{5}-31 \mathrm{CaO} \\
\mathrm{mol} \%\end{array}$ & $\begin{array}{l}\text { Freeze-drying } \\
\text { technique }\end{array}$ & $\begin{array}{c}\text { Total porosity }=80 \% \text {; micro-sized porous } \\
\text { surface structure }=200-500 \mu \mathrm{m} \text {; elastic } \\
\text { modulus }=64 \pm 1.3 \mathrm{MPa} \text {; compressive } \\
\text { yield strength }=4.3 \pm 0.23 \mathrm{MPa} \text {. } \\
\text { No cytotoxic effects; good viability of } \\
\text { cells in vitro. Woven bone tissue } \\
\text { formation in vivo }\end{array}$ & $\begin{array}{l}\text { Scaffolds for } \\
\text { bone defects }\end{array}$ & [113] \\
\hline $\begin{array}{c}\mathrm{nBG}\left(64 \mathrm{SiO}_{2}\right. \\
-5 \mathrm{P}_{2} \mathrm{O}_{5}^{-} \\
31 \mathrm{CaO} \mathrm{mol} \%)\end{array}$ & $\begin{array}{l}\text { Layer solvent } \\
\text { casting combined } \\
\text { with freeze-drying } \\
\text { and lamination } \\
\text { techniques }\end{array}$ & $\begin{array}{c}\text { Pore size }=200-500 \mu \mathrm{m} \text {; elastic modulus } \\
=50-80 \mathrm{MPa} . \text { Good cellular migration } \\
\text { and osteoconductivity }\end{array}$ & $\begin{array}{l}\text { Scaffolds for } \\
\text { tissue } \\
\text { engineering }\end{array}$ & [114] \\
\hline $\begin{array}{c}\mathrm{BaG}\left(64 \mathrm{SiO}_{2}\right. \\
-5 \mathrm{P}_{2} \mathrm{O}_{5}^{-} \\
\left.31 \mathrm{CaO} \mathrm{mol}^{-}\right)\end{array}$ & $\begin{array}{l}\text { Layer solvent } \\
\text { casting combined } \\
\text { with freeze-drying } \\
\text { and lamination } \\
\text { techniques }\end{array}$ & $\begin{array}{l}\text { Parallel aligned and inter-connected } \\
\text { pores }=200-500 \mu \mathrm{m} ; \text { porosity }=70-86 \% ; \\
\text { Young's modulus }=50-80 \mathrm{MPa} \text {. } \\
\text { Improved attachment and penetration of } \\
\text { cells into the pores }\end{array}$ & $\begin{array}{l}\text { Scaffolds for } \\
\text { bone tissue } \\
\text { engineering }\end{array}$ & [115] \\
\hline $\begin{array}{c}\mathrm{BaG}\left(64 \mathrm{SiO}_{2}\right. \\
-5 \mathrm{P}_{2} \mathrm{O}_{5}^{-} \\
\left.31 \mathrm{CaO} \mathrm{mol}^{-}\right)\end{array}$ & $\begin{array}{l}\text { Freeze-drying } \\
\text { technique }\end{array}$ & $\begin{array}{c}\text { Pore size }=200-500 \mu \mathrm{m} ; \\
\text { porosity }=70-86 \% . \\
\text { Young's modulus: } \\
10 \% \mathrm{BaG}=51 \pm 1.8 \mathrm{MPa}, \\
20 \% \mathrm{BaG}=58 \pm 2.1 \mathrm{MPa}, \\
30 \% \mathrm{BaG}=64 \pm 1.3 \mathrm{MPa}, \\
40 \% \mathrm{BaG}=72 \pm 1.7 \mathrm{MPa}, \\
50 \% \mathrm{BaG}=78 \pm 1.2 \mathrm{MPa} . \mathrm{Compressive} \\
\text { yield strength: } 10 \% \mathrm{BaG}=2.8 \pm 0.26 \mathrm{MPa}, \\
20 \% \mathrm{BaG}=3.7 \pm 0.19 \mathrm{MPa}, \\
30 \% \mathrm{BaG}=4.3 \pm 0.23 \mathrm{MPa}, \\
40 \% \mathrm{BaG}=4.9 \pm 0.30 \mathrm{MPa}, \\
50 \% \mathrm{BaG}=5.6 \pm 0.61 \mathrm{MPa} . \text { Improved cell } \\
\text { culture response }\end{array}$ & $\begin{array}{l}\text { Scaffolds for } \\
\text { bone tissue } \\
\text { engineering } \\
\text { implant }\end{array}$ & [116] \\
\hline $45 \mathrm{~S} 5$ & Casting technique & Tensile stress $=0.75-2.1 \mathrm{MPa}$ & $\begin{array}{l}\text { Films for soft } \\
\text { tissue } \\
\text { engineering }\end{array}$ & [117] \\
\hline $\begin{array}{c}70 \mathrm{SiO}_{2}-25 \mathrm{CaO}-5 \mathrm{P}_{2} \mathrm{O}_{5} \\
\mathrm{~mol} \%\end{array}$ & $\begin{array}{l}\text { Electrospinning } \\
\text { technique }\end{array}$ & $\begin{array}{c}\text { Free from bead-like defects; average fiber } \\
\text { diameter }=192 \pm 8 \mathrm{~nm} \text {; tensile strength }= \\
4.3 \pm 1.2 \mathrm{MPa} \text {; elongation to failure = } \\
168 \pm 14 \% .14 \text { days after seeding, surfaces } \\
\text { covered by multicellular layers; improved } \\
\text { ALP activity }\end{array}$ & $\begin{array}{l}\text { Hybrid scaffolds } \\
\text { for bone } \\
\text { regeneration }\end{array}$ & [118] \\
\hline
\end{tabular}


Table 2. Cont.

\begin{tabular}{|c|c|c|c|c|}
\hline Bioactive Glass & Technique & Composites' Characteristics & Applications & Ref. \\
\hline $\mathrm{BG}\left(75 \mathrm{SiO}_{2}-25 \mathrm{CaO} w \mathrm{t} \%\right)$ & Sol-gel method & $\begin{array}{c}\text { Porosity }=90 \% \text {; after immersion in } \\
\text { physiological fluids: compressive } \\
\text { strength of class I (without covalent } \\
\text { linkages between organic-inorganic } \\
\text { networks) BG-gelatin = } 1 \mathrm{kPa} \text { at } 10 \% \\
\text { deformation and of class II (with covalent } \\
\text { linkages between organic- inorganic } \\
\text { networks) BG-gelatin = } 108 \mathrm{kPa} \text { at } 10 \% \\
\text { deformation; Young's modulus class II } \\
\text { BG-gelatin = 5-166 MPa; yield strength } \\
\text { class II BG-gelatin }=0.2-4 \mathrm{MPa}\end{array}$ & $\begin{array}{l}\text { Hybrid scaffolds } \\
\text { for bone } \\
\text { regenerative } \\
\text { medicine and } \\
\text { tissue } \\
\text { engineering }\end{array}$ & [119] \\
\hline $70 \mathrm{~S} 30 \mathrm{C}$ & $\begin{array}{l}\text { Modified direct } \\
\text { foaming technique }\end{array}$ & $\begin{array}{l}\text { Modal pore size }=160-170 \mu \mathrm{m} \text {; effective } \\
\text { stiffness }=5.87 \pm 2.22 \mathrm{MPa} \text {; maximum } \\
\text { compressive strength }=0.32 \pm 0.03 \mathrm{MPa} \text {. } \\
\text { Samples crosslinked: approximate } \\
\text { stiffness }=7.19 \pm 2.78 \mathrm{MPa} \text {, compressive } \\
\text { strength }=0.24 \pm 0.04 \mathrm{MPa} \text {. Rapid } \\
\text { formation of apatite in SBF; excellent cell } \\
\text { attachment } 3 \text { days after seeding }\end{array}$ & $\begin{array}{l}\text { Scaffolds for } \\
\text { bone } \\
\text { augmentation } \\
\text { and clinical } \\
\text { applications }\end{array}$ & {$[120]$} \\
\hline $\begin{array}{c}70 \mathrm{SiO}_{2}-25 \mathrm{CaO}-5 \mathrm{P}_{2} \mathrm{O}_{5} \\
\mathrm{~mol} \%\end{array}$ & $\begin{array}{l}\text { Solid free form } \\
\text { fabrication (SFF) } \\
\text { method }\end{array}$ & $\begin{array}{l}\text { Large shrinkage after deposition and } \\
\text { drying }=33 \% \text { linear shrinkage in the } \\
\text { plane of deposition and } 40-50 \% \text { in } \\
\text { thickness; compressive strength }= \\
3.7 \pm 0.2 \mathrm{MPa} \text {; compressive strength } \\
\text { crosslinked = 5.1 } \pm 0.6 \mathrm{MPa} \text {. Enhanced } \\
\text { proliferation, ALP activity, and } \\
\text { mineralization of osteogenic MC3T3-E1 } \\
\text { (line of mouse pre-osteoblastic cells) } \\
\text { in vitro }\end{array}$ & $\begin{array}{l}\text { Hybrid scaffolds } \\
\text { for bone } \\
\text { regeneration }\end{array}$ & [121] \\
\hline $75 \mathrm{SiO}_{2}-25 \mathrm{CaO}$ wt $\%$ & $\begin{array}{l}\text { Mixing solution } \\
\text { and drying }\end{array}$ & $\begin{array}{c}\text { Total porosity }=91 \pm 1 \% \text {; average pore } \\
\text { size }=187 \pm 6 \mu \mathrm{m} \text { with pores ranging } \\
\text { from } 105 \text { to } 295 \mu \mathrm{m} \text {; average } \\
\text { interconnection diameter }=74 \pm 4 \mu \mathrm{m} \\
\text { with diameters ranging from } 25 \text { to } 115 \mu \mathrm{m}\end{array}$ & $\begin{array}{l}\text { Scaffolds for } \\
\text { tissue } \\
\text { engineering }\end{array}$ & [122] \\
\hline $\begin{array}{c}45 \mathrm{~S} 5, \mathrm{BG} / \mathrm{Sr} \\
\left(\mathrm{SiO}_{2}-\mathrm{CaO}-\mathrm{SrO}-\mathrm{P}_{2} \mathrm{O}_{5}\right) \\
\mathrm{Gel}=\text { gelatin }\end{array}$ & $\begin{array}{l}\text { Freeze-drying } \\
\text { technique }\end{array}$ & 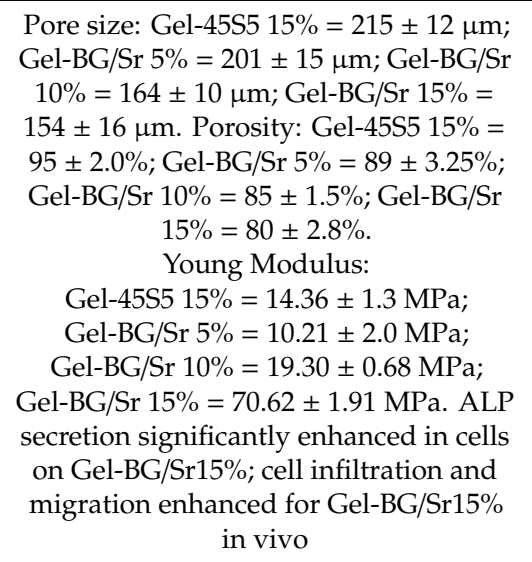 & $\begin{array}{l}\text { Scaffolds for } \\
\text { bone tissue } \\
\text { engineering }\end{array}$ & [123] \\
\hline $\mathrm{SiO}_{2}-\mathrm{CaO}-\mathrm{P}_{2} \mathrm{O}_{5}-\mathrm{MgO}-\mathrm{ZnO}$ & $\begin{array}{l}\text { Freeze-drying } \\
\text { technique }\end{array}$ & $\begin{array}{c}\text { Pore diameter in the range of } 100-500 \mu \mathrm{m} ; \\
\text { average Young's modulus }=28 \pm 2 \mathrm{MPa} ; \\
\text { average yield strength }=4 \pm 0.4 \mathrm{MPa} \text {. } \\
\text { Insignificant reduction in cells } \\
\text { proliferation and no severe toxicity }\end{array}$ & $\begin{array}{l}\text { Scaffolds for } \\
\text { bone tissue }\end{array}$ & {$[124]$} \\
\hline
\end{tabular}


Table 2. Cont.

\begin{tabular}{|c|c|c|c|c|}
\hline Bioactive Glass & Technique & Composites' Characteristics & Applications & Ref. \\
\hline $\begin{array}{l}\mathrm{BG}\left(60 \mathrm{SiO}_{2}-36 \mathrm{CaO}-4 \mathrm{P}_{2} \mathrm{O}_{5}\right. \\
\mathrm{mol} \%) \text { mixed } 0 \mathrm{wt} \%, 1 \\
\text { wt } \%, 2 \mathrm{wt} \%, 3 \mathrm{wt} \% \\
4 \mathrm{wt} \% \text { tetrapod-like } \mathrm{ZnO} \\
\text { whiskers (indicated as } \\
\text { BGZ0, BGZ1, BGZ2, } \\
\text { BGZ3, BGZ4) }\end{array}$ & $\begin{array}{l}\text { Freeze-drying } \\
\text { technique }\end{array}$ & 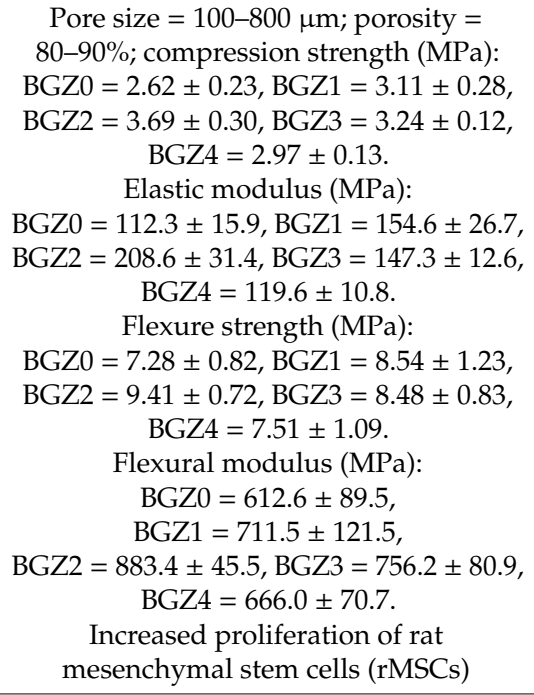 & $\begin{array}{l}\text { Scaffolds for } \\
\text { bone repair }\end{array}$ & {$[125]$} \\
\hline Silver nanoparticles, $63 \mathrm{~S}$ & $\begin{array}{l}\text { Freeze-drying and } \\
\text { crosslinking } \\
\text { technique }\end{array}$ & $\begin{array}{c}\text { Pore size of gelatin/nanosilver/bioactive } \\
\text { glass scaffolds }=350-635 \mu \mathrm{m} \text {. } \\
\text { Gelatin/nanosilver scaffolds high water } \\
\text { uptake; gel fraction }=70-85 \% \text {. Improved } \\
\text { human mesenchymal stem cells (hMSC) } \\
\text { viability. Antibacterial effects against E. } \\
\text { coli and S. aureus }\end{array}$ & $\begin{array}{l}\text { Antibacterial } \\
\text { scaffolds for } \\
\text { bone tissue } \\
\text { engineering }\end{array}$ & [126] \\
\hline $\begin{array}{c}\mathrm{Cu}-\mathrm{BGN} \\
\left(95 \mathrm{SiO}_{2}-2.5 \mathrm{CaO}-2.5 \mathrm{CuO}\right. \\
\mathrm{mol} \%)\end{array}$ & $\begin{array}{l}\text { Dip coating } \\
\text { technique }\end{array}$ & $\begin{array}{c}\text { Porosity }=91 \% \text {; The obtained scaffolds } \\
\text { were designated as } 5 \mathrm{Cu}-\mathrm{BGS} \text { and } \\
\text { 20Cu-BGS according to the ratios (in } \mathrm{wt} \% \text { ) } \\
\text { of } \mathrm{Cu}-\mathrm{BGN} / \text { gelatin used ( } 5 \text { and } 20 \mathrm{wt} \% \text { ). } \\
\text { Compressive strength: } \\
\text { 0Cu-BGS }=1.3 \pm 0.2 \mathrm{MPa} \text {, } \\
5 \mathrm{Cu}-\mathrm{BGS}=1.2 \pm 0.2 \mathrm{MPa}, 20 \mathrm{Cu}-\mathrm{BGS}= \\
0.7 \pm 0.3 \mathrm{MPa} \text {. Good HCA formation; } \\
\text { improved mouse preosteoblastic cell lines } \\
\text { (MC3T3-E1) proliferation and improved } \\
\text { osteogenic activity }\end{array}$ & $\begin{array}{l}\text { Coatings on BG } \\
\text { scaffolds for } \\
\text { bone } \\
\text { regeneration/repair }\end{array}$ & [127] \\
\hline
\end{tabular}

\subsection{Silk Fibroin/Bioactive Glass Composites}

Silkworm Bombyx mori (B. mori) and various species of spiders secrete silk fibroin, which is a natural fibrous protein. Since spiders' silks are different in nature, usually, silks from silkworm are used to fabricate silk-based biomaterials [128]. The raw silk is made of two parallel fibroin fibers held together with a layer of sericin on their surfaces [129]. Sericin should be removed, because it is thought to be responsible for allergic and inflammatory reaction. The fibroin fibers appear shiny and soft to the touch after the degumming process to remove sericin [129]. A light (L) chain polypeptide and heavy (H) chain polypeptide linked together make up the structure of silk fibroin through the formation of the H-L complex [129]. The superior mechanical properties of silk fibroins depend on the $\mathrm{H}$ chain, which can form $\beta$-sheet crystallites, while the $L$ chain has a small role in the mechanical properties of silk fibroin due to its smaller size [129]. In general, increased $\beta$-sheet content has a protective effect on silk degradation, which is likely in part due to the fact that most proteases act outside of the $\beta$-sheet regions [130].

Silk fibroin has been widely used for its advantageous strength, biodegradability, elasticity, and low tissue reactivity [12]. In fact, silk fibroin has attractive mechanical properties showing a balance of modulus, breaking strength, and elongation. The hierarchical structure of silk as well as the health of the silkworm (from which silk fibroin is obtained) influence the mechanical properties of silk fibroin [129]. For these favorable properties, silk fibroin has been used as a biomaterial to produce 
scaffolds, sponges, hydrogels, films, and mats for tissue engineering applications (i.e., vascular tissue, neural tissue, bone tissue [131], cartilage, ligament and tendon tissues [132], wound dressing [133], hepatic tissue, tracheal tissue, etc.).

Although it has these impressive properties, silk fibroin lacks the potential to induce osteogenesis, which is of pivotal importance, especially in bone tissue applications. Therefore, bioactive ceramics (i.e., hydroxyapatite, $\beta$-tricalcium phosphates, bioactive glasses) have been added to silk fibroin to fabricate composites that are able to mimic the bone structures.

Among bioactive ceramics, bioactive glasses (BGs) possess greater osteoconductive capacity and a greater ability to bond to bone without forming fibrous tissue. In addition, bioactive glass particles act as reinforcement being beneficial for mechanical properties as well. Indeed, mesoporous bioactive glass (MBG)/silk fibroin scaffolds showed improved compressive strength and better spreading of cells compared to pure silk scaffolds [134] and to non-mesoporous glass/silk scaffolds [135]. Although mesoporous glass destroys the inner structure of silk fibroin, it shows a larger surface area and pore volume with respect to non-mesoporous glass. Thus, during the fabrication process, part of the solution of silk fibroin can enter into the pores of mesoporous glass leading to a stronger bond with silk fibroin after freeze-drying [135]. Additionally, mesoporous glass/silk fibroin scaffolds showed a better apatite mineralization ability probably due to the faster dissolution rate $[135,136]$. The faster dissolution rate may give a favorable environment for cell adhesion and proliferation and for further tissue growth.

The interaction between biomaterials and cells is known to be a crucial process for the following bone mineralization. Human mesenchymal stem cells (hMSC) cells on silk fibroin hierarchical scaffolding matrices functionalized by a $\mathrm{Cu}$-containing bioactive glass $\left(70 \mathrm{~S}, 70 \mathrm{SiO}_{2}-22 \mathrm{CaO}-5 \mathrm{P}_{2} \mathrm{O}_{5}-3 \mathrm{CuO}\right.$ molar ratio) coating were found to go toward a differentiated osteoblast phenotype [137]. The $\mathrm{Cu}$-containing bioactive glass coatings improved the ingrowth of new bone tissue in vivo [137].

Ideal scaffolds should possess a structure that mimics the structure of the host tissues in terms of porosity, mechanical, and biological properties to facilitate osteoinduction, vascularization, and tissue formation. In recent years, various strategies to achieve a better control of the micro and macro structural features of scaffolds have been developed ranging from the biphasic structure [138] to an indirect 3D printing technique [139]. The biphasic scaffolds were developed by an electrospinning technique and the two phases (i.e., bioactive glass and silk fibroin) preserved their own porous structure, resulting in good integration at the same time [138]. Therefore, the bioactive glass phase, which has the capability to enhance the osteogenic precursor cells, and the silk fibroin phase, which is able to drive the tissue regeneration, constitute the biphasic scaffolds. In vitro experiments demonstrated an enhanced ALP activity and the absence of adverse immune response [138]. An enhanced ALP activity was also shown by bioactive glass/silk fibroin scaffolds fabricated by an indirect 3D printing technique [139]. The differentiation of osteoblasts was enhanced by the releasing of ions from BGs [139]. Indeed, the incorporation of bioactive glass improved the biological performance of silk fibroin scaffolds, mediating cellular response. The release of ions and surface features such as roughness and hydrophilicity greatly influenced the biological performance. The high hydrophilic nature of bioactive glass/silk fibroin composites compared to pure silk composites enhanced the interaction with cells, which is further improved by BGs, which release ions. Nano bioactive glass particles embedded into silk fibroin films were shown to enhance the hydrophilic nature of silk fibroin, its bioactivity, and ALP activity in in vitro tests [140]. The increase of nano bioactive glass particles in silk fibroin films resulted in more silanol groups on the films surface, which in turn generated an increase in cellular activity. Previous studies have shown that silanol groups bind to proteins through different functional groups, producing a favorable surface environment for cell growth [140].

Table 3 summarizes silk fibroin/bioactive glass composites. 
Table 3. Summary of silk fibroin/bioactive glass composites for various biomedical applications.

\begin{tabular}{|c|c|c|c|c|}
\hline Bioactive Glass & Technique & Composites' Characteristics & Applications & Ref. \\
\hline $\begin{array}{l}\text { MBG (mesoporous } \\
\text { bioactive glass) }\end{array}$ & $3 \mathrm{D}$ printing & $\begin{array}{l}\text { Compressive strength }=19.9 \pm 0.6 \mathrm{MPa} . \\
\text { Improved ALP activity. Expression of bone } \\
\text { morphogenic protein }(\mathrm{BMP}-2)=0.22 \pm 0.05\end{array}$ & $\begin{array}{l}\text { Scaffolds for } \\
\text { bone tissue } \\
\text { engineering }\end{array}$ & [134] \\
\hline $\begin{array}{c}\text { Non-mesoporous glass BG, } \\
\text { mesoporous bioactive glass } \\
\text { MBG }(\mathrm{Si} / \mathrm{Ca} / \mathrm{P}=80 / 15 / 5 \\
\mathrm{mol} \%)\end{array}$ & $\begin{array}{l}\text { Freeze-drying } \\
\text { technique }\end{array}$ & $\begin{array}{l}\text { Porosity: MBG/silk }=76 \pm 4 \% \text {; BG/silk }=76 \pm 2 \% \text {. } \\
\text { Compressive strength: MBG/silk }=420 \mathrm{kPa} \text {, } \\
\text { BG/silk }=300 \mathrm{kPa} \text {. Compressive modulus: } \\
\mathrm{MBG} / \text { silk }=0.7 \mathrm{MPa} \text { BG/silk = 0.5 MPa. MBG/silk } \\
\text { and BG/silk good bone repair ability }\end{array}$ & $\begin{array}{l}\text { Scaffolds for } \\
\text { bone tissue } \\
\text { repair }\end{array}$ & [135] \\
\hline $\begin{array}{l}\text { Mesoporous bioactive glass } \\
\text { nanoparticles (MBGNs) }\end{array}$ & $\begin{array}{l}\text { Freeze-drying } \\
\text { technique }\end{array}$ & $\begin{array}{l}\text { Pore diameter }=36.2 \pm 9.3 \mu \mathrm{m} . \text { Good adhesion } \\
\text { and spreading and proliferation of bone marrow } \\
\text { stromal cells (BMSCs) }\end{array}$ & $\begin{array}{l}\text { Scaffolds for } \\
\text { orthopedic } \\
\text { applications }\end{array}$ & [136] \\
\hline $\begin{array}{c}70 \mathrm{~S} \\
\left(\begin{array}{c}70 \mathrm{SiO}_{2}-22 \mathrm{CaO}-5 \mathrm{P}_{2} \mathrm{O}_{5}-3 \mathrm{CuO} \\
\mathrm{mol} \%)\end{array}\right.\end{array}$ & $\begin{array}{l}\text { Freeze-drying } \\
\text { and } \\
\text { lyophilization } \\
\text { technique }\end{array}$ & $\begin{array}{c}\text { Average pore size: } \\
\text {-silk fibroin scaffolds without reinforcement } \\
175-145 \mu \mathrm{m} \text {; } \\
\text {-silk fibroin matrices reinforced with unmodified } \\
\text { silk microfibers } 112-143 \mu \mathrm{m} ; \\
\text {-composite silk fibroin matrices reinforced with } \\
\text { functionalized silk microfibers } 108-119 \mu \mathrm{m} \text {. } \\
\text { Compressive strength: } \\
\text { Silk fibroin matrices reinforced with } \\
\text { functionalized silk microfibers } 91-123 \mathrm{kPa} \text {. } \\
\text { Favored homing of endothelial cells through } \\
\text { C-X-C chemokine receptor type } 4 \text { (CXCR4/SDF-1) } \\
\text { signaling in vitro. Facilitated the neo-osseous } \\
\text { tissue formation in vivo }\end{array}$ & $\begin{array}{l}\text { Scaffolds as } \\
\text { resorbable } \\
\text { bone grafts }\end{array}$ & [137] \\
\hline $\begin{array}{c}70 \mathrm{~S}\left(70 \mathrm{SiO}_{2}-25 \mathrm{CaO}-5 \mathrm{P}_{2} \mathrm{O}_{5}\right. \\
\mathrm{mol} \%)\end{array}$ & $\begin{array}{l}\text { Electrospinning } \\
\text { technique }\end{array}$ & $\begin{array}{l}\text { Contact angle bioactive glass/silk fibroin (B. mori } \\
\text { silk) biphasic: } \\
\text { Silk fibroin side }=73.51 \pm 1.8^{\circ}, \text { bioactive glass side } \\
=24.2 \pm 2.2^{\circ} ; \text { contact angle bioactive glass/silk } \\
\text { fibroin }(\mathrm{A} \text {. assama) biphasic: } \\
\text { Silk fibroin side }=47.14 \pm 2.9^{\circ}, \text { bioactive glass side } \\
=51.23 \pm 2.2^{\circ} \text {. Elastic modulus: bioactive } \\
\text { glass/silk fibroin (B. mori silk) }=29.36 \pm 1.38 \mathrm{MPa} ; \\
\text { bioactive glass/silk fibroin (A. assama) }= \\
27.48 \pm 3.96 \mathrm{MPa} \text {. Elongation at break: bioactive } \\
\text { glass/silk fibroin (B. mori silk) }=2.28 \pm 0.59 \% ; \\
\text { bioactive glass/silk fibroin (A. assama) }= \\
8.52 \pm 1.43 \% \text {. Enhanced ALP activity }\end{array}$ & $\begin{array}{l}\text { Biphasic } \\
\text { scaffolds for } \\
\text { osteochondral } \\
\text { tissue repair }\end{array}$ & [138] \\
\hline $45 \mathrm{~S} 5$ & $\begin{array}{l}\text { Combination of } \\
\text { indirect 3D } \\
\text { inkjet printing } \\
\text { and } \\
\text { freeze-drying } \\
\text { methods }\end{array}$ & $\begin{array}{c}\text { Size of macropores }=500-600 \mu \mathrm{m} \text {; pore size }= \\
20-30 \mu \mathrm{m} \text {. Water uptake: silk fibroin }(\mathrm{SF}) \text { and } \\
45 \mathrm{~S} 5 \text { nanoparticles }(\mathrm{nBG}) \text { while } 45 \mathrm{~S} 5 \\
\text { microparticles }(\mu \mathrm{BG}) \mathrm{SF}-\mathrm{nBG}=85.19 \pm 1.6 \% \\
\mathrm{SF}-\mu \mathrm{BG}=87.14 \pm 0.86 \% \text {; } \text { swelling ratios: SF-nBG } \\
=5.79 \pm 0.76 \%, \mathrm{SF}-\mu \mathrm{BG}=6.79 \pm 0.5 \% \text {. Contact } \\
\text { angle: SF-nBG }=63.65 \pm 0.74^{\circ}, \mathrm{SF}-\mu \mathrm{BG}= \\
73.9 \pm 0.72^{\circ} . \text { Compressive strength: SF-nBG } \\
942 \pm 81 \mathrm{kPa}, \mathrm{SF}-\mu \mathrm{BG}=1210 \pm 80 \mathrm{kPa} ; \\
\text { compressive modulus: SF-nBG = } 8660 \pm 660 \mathrm{kPa} \text {, } \\
\text { SF- } \mu \mathrm{BG}=10353 \pm 620 \mathrm{kPa} \text {. Viability of cell } \\
\text { significantly high on SF-nBG; high ALP activity } \\
\text { on SF-nBG and SF- } \mu \mathrm{BG}\end{array}$ & $\begin{array}{l}\text { Scaffolds for } \\
\text { bone tissue } \\
\text { regeneration } \\
\text { in high } \\
\text { load-bearing } \\
\text { applications }\end{array}$ & [139] \\
\hline $\begin{array}{c}58 \mathrm{sNBG} \\
\left(58 \mathrm{SiO}_{2}-23 \mathrm{CaO}-9 \mathrm{P}_{2} \mathrm{O}_{5} \mathrm{wt} \%\right)\end{array}$ & $\begin{array}{l}\text { Solvent casting } \\
\text { method }\end{array}$ & $\begin{array}{l}\text { Thickness }=50-200 \mu \mathrm{m} . \text { Water contact angle }= \\
60-67^{\circ} . \text { Improved hydrophilicity and in vitro } \\
\text { bioactivity. Enhanced proliferation of osteoblasts }\end{array}$ & $\begin{array}{l}\text { Films for } \\
\text { bone tissue } \\
\text { engineering }\end{array}$ & [140] \\
\hline
\end{tabular}

\section{Natural Polymers: Polysaccharides}

Polysaccharides derive from both plant and animal sources and therefore are widely distributed in nature. There are hundreds of known polysaccharides, and they can be categorized based on their type of sources: (i) animals (i.e., hyaluronic acid, chitin, chitosan); (ii) algal (i.e., alginates, galactans, and carrageenan); (iii) plants (i.e., starch, cellulose, arabic gum); and (iv) microorganisms (i.e., dextran, gellan gum, and xanthan gum). The position of O-glycosidic linkages, the molecular weight, and the 
chain of polysaccharides strongly influence their physical and chemical properties [12]. A considerable number of polysaccharides are water soluble and oxidize beyond their melting point when elevated temperatures are reached. Their tunable degradation and their feasibility make them appropriate for numerous biomedical applications.

\subsection{Hyaluronic Acid/Bioactive Glass Composites}

Hyaluronic acid or hyaluronate is a linear polysaccharide constituted by repeating the disaccharide unit of $\beta(1,4)$-glucuronic acid (GlcUA)- $\beta(1,3)-\mathrm{N}$-acetylglucosamine. Hyaluronic acid is one of the principal parts of extracellular matrix (ECM) [141,142], and it promotes cellular migration and proliferation. The inevitable drawbacks in the extraction process of hyaluronic acid from animal sources are (i) the endogenous hyaluronidase activity in animal tissues and (ii) the difficult conditions of extraction [143]. Additionally, although the hyaluronic acid extracted from animal sources should be extensively purified from contaminants (i.e., proteins and nucleic acids) to reach the high-quality standards for medical applications, the extraction from animal sources remains the principal technology used for commercial products [143], and it is still the most important source for hyaluronic acid. On the other hand, hyaluronic acid can be also synthesized from enzymes; this process still represents a new perspective that can reduce the contamination risks caused by the extraction from animal waste [143].

Hyaluronic acid, along with being used as a component of body lotions, has been used for defective bones and teeth due to its capacity to avoid toxicity, inflammatory, and immunogenicity response in the host. Hyaluronic acid is generally coupled with other polymers (i.e., cohesion promoters) such as chitosan and alginate to improve washout resistance [144,145]. Therefore, hyaluronic acid did not represent the principal polymer used to develop composites [146-149]. However, hyaluronic acid is selected as a source of polymeric solution because of its excellent biocompatibility, viscoelastic characteristic, and because it is involved in the production of extracellular matrix (ECM) by operating as an organizing core to connect complex intracellular aggregates [150]. Therefore, hyaluronic acid was selected as a polymeric solution by Sohrabi et al. [151] to develop composite injectable pastes with the introduction of bioactive glasses (BGs). The addition of BGs allowed the formation of direct chemical bonds to surrounding tissues, due to their bioactivity and osteoconductivity. Composite injectable pastes must be injected without any resistance and phase separation; the different morphology of bioactive glass embedded into hyaluronic acid influenced the rheological properties of pastes. Bioactive glass particles with high pore volume and low size of particles induce high viscosity of paste. This behavior is probably caused by the penetration of liquids in some pores of BGs reducing available liquid between particles [151]. Although in vitro investigations are surely needed, hyaluronic acid/bioactive glass pastes were developed without coupling polymers [151].

Table 4 summarizes the hyaluronic acid/bioactive glass composite using hyaluronic acid only, without other blending polymers.

Table 4. Summary of hyaluronic/bioactive glass composites.

\begin{tabular}{|c|c|c|c|c|}
\hline Bioactive Glass & Technique & Composites' Characteristics & Applications & Ref. \\
\hline $64 \mathrm{SiO}_{2}-31 \mathrm{CaO}-5 \mathrm{P}_{2} \mathrm{O}_{5}$ & $\begin{array}{l}\text { Manually } \\
\text { mixing }\end{array}$ & $\begin{array}{l}\text { Better apatite formation ability of } \\
\text { bioactive glass/hyaluronic acid } \\
\text { (BG2-HAc) compared to bioactive } \\
\text { glass/hyaluronic acid (BG1-HAc), } \\
\text { where BG1 is the bioactive glass } \\
\text { developed by a one-step } \\
\text { acid-catalyzed process, while } \\
\text { two-step acid-base sol-gel processing } \\
\text { was used to produce BG2 bioactive } \\
\text { glass. BG2/HAc paste had higher } \\
\text { viscosity than BG1/HAc paste. }\end{array}$ & $\begin{array}{c}\text { Injectable pastes } \\
\text { for the treatment of } \\
\text { hard and even soft } \\
\text { tissues }\end{array}$ & [151] \\
\hline
\end{tabular}




\subsection{Chitosan/Bioactive Glass Composites}

Chitosan is a linear polysaccharide formed by a deacetylated unit ( $\beta$-(1-4)-linked d-glucosamine) and acetylated unit ( $\mathrm{N}$-acetyl-d-glucosamine) distributed in a random manner. Chitosan is obtained from shrimps and shells of various crustaceans using alkali $\mathrm{NaOH}$ to eliminate the acetamide group (i.e., deacetylation). Deacetylation is never complete: it varies from $30 \%$ to $95 \%$.

Chitosan biocompatibility decreases with increasing (i) deacetylation degree (DD), (ii) solubility, and (iii) degradation rate. Additionally, the solubility of chitosan is influenced by the positive charge of amino groups; in fact, chitosan is soluble in diluted acid $(\mathrm{pH}<6)$ only. Furthermore, the hemostatic activity of chitosan is promoted by its positive charge, which is able to bond the negative charge of the membranes of blood cells [152,153]. In fact, chitosan interacts with erythrocyte membranes, attracting platelets and accelerating clot formation [12,153]. The amine and hydroxylic groups enhance the growth of osteoblast and the bone formation in vivo [152,154,155]; the chemical backbone of chitosan is similar to glycosaminoglycan, which is a major component of bones and cartilages. Therefore, chitosan is a suitable candidate for bone grafts [156,157]. Additionally, although the mechanism is still unknown [158-160], chitosan shows antimicrobial effects. Two possible mechanisms are considered: (i) the negative charge of chitosan alters the permeability of the membranes of bacteria; and (ii) chitosan prevent the synthesis of RNA by bonding the DNA of bacteria [152,161].

Therefore, chitosan possesses excellent biocompatibility, biodegradability, and antimicrobial effects being a suitable biomaterial for biomedical devices. However, chitosan has low mechanical properties, especially for load-bearing bones [162,163]. To solve this problem by offering synergistic effects among mechanical properties, biocompatibility, and bioactivity, bioactive glasses (BGs) have been widely added to pure chitosan [164]. The improved mechanical properties of chitosan/BG composites were attributed to the addition of BGs, which increased the hardness of chitosan by distributing the applied stress and inhibiting cracks propagation. In general, the addition of BG particles higher than $12.5 \% \mathrm{w} / \mathrm{w}$ led to a significant increase in the storage modulus and specific storage modulus of hydrogels [165]. Presumably, the bonding between the BG surface and chitosan functional groups served to maintain the dispersion of the BG within the chitosan matrix, resulting in better mechanical properties. This hypothesis was corroborated by the storage and loss moduli obtained for bioactive glass-injectable systems, which increased with an increasing amount of BG [166]. Furthermore, the addition of BG nanoparticles also improved the hardness of chitosan fibers as shown in [167]; this enabled also a distribution of the applied stresses over the entire structure of the composite. The compressive strength of chitosan/ $\mathrm{BG}\left(6 \mathrm{Na}_{2} \mathrm{O}, 8 \mathrm{~K}_{2} \mathrm{O}, 8 \mathrm{MgO}, 22 \mathrm{CaO}, 54 \mathrm{~B}_{2} \mathrm{O}_{3}, 2 \mathrm{P}_{2} \mathrm{O}_{5}\right.$ mol \%) injectable cement well matched the compressive strength of human trabecular and cortical bone [168]. Therefore, chitosan/BG injectable cement could be suitable for healing non-load bearing and load-bearing defects of bone.

Biomaterials are usually employed under hydrated condition (i.e., physiological fluids), which could strongly affect their mechanical properties: such properties are different than the ones under dry condition. In this regard, the mechanical properties of $\mathrm{SiO}_{2}: \mathrm{CaO}: \mathrm{P}_{2} \mathrm{O}_{5}=55: 40: 5 \mathrm{~mol} \%$ nanoparticles (BG-NPs) scaffolds were tested under hydrated condition [169], and chitosan/bioactive glass membranes for periodontal regeneration were investigated under both dry and wet conditions [170], since the mechanical properties affect both clinical application and the bone-healing capacity of composites [171,172]. The metabolic activity of cells on chitosan/bioactive glass membranes was higher compared to pure chitosan membranes, indicating a positive effect of bioactive glass incorporation [170]. Therefore, the development of composites aimed at finding a balance between biological performance [173-175] and stable structure under mechanical stresses.

The design of the implant's features, such as the porosity and interconnected pores $[176,177]$ to allow cells migration and nutrients, is relevant as well as ions released from implants. The ionic products of BGs stimulate cell viability and proliferation. For instance, Si ions promoted the production of collagen I and enhanced osteoblastic differentiation [84,105,178,179] and extracellular matrix 
differentiation $[87,89,180]$. Additionally, Si ions activated Ca-sensing receptors in osteoblast cells, increasing the expression of insulin-like growth factors (i.e., IGF-I or IGF-II) $[49,181-183]$.

Higher cellular viability and a stronger bone formation of chitosan/bioactive glass with high bioactive glass content were measured by Khoshakhlagh et al. [184] compared to that of chitosan/bioactive glass with lower bioactive glass content. By controlling the amount of bioactive glasses inside the chitosan matrix, the degradation rate and the cellular viability could be affected. In addition, by tailoring the chemical composition of bioactive glasses by the addition of different ions (i.e., $\mathrm{Sr}, \mathrm{Mg}, \mathrm{Zn}, \mathrm{Ga}, \mathrm{Cu}$ ), it was possible to stimulate cellular specific responses [178,185]. For instance, Sr ions promoted cellular activity through the membrane-bond Ca-sensing receptor in both osteoblasts and osteoclasts [186-188]. Furthermore, Sr ions demonstrated stimulatory effects on osteoblasts, resulting in an increase in bone density and resistance [189-192]. Indeed, the injectable cement of chitosan and Sr-containing bioactive glasses (CS/SrBG) developed by Zhang et al. [193] significantly enhanced the expression of osteogenic genes and type I collagen, which is an early terminal osteoblast differentiation [192,194]. In vivo CS/SrBG cement enhanced osteogenesis, stimulated bone formation, and showed higher bone-implant contact compared to chitosan/bioactive glass cements without $\mathrm{Sr}$ ions. The better ability in improving bone regeneration and bone implant contact was due to the ability of CS/SrBG (i) to mineralize to hydroxy carbonate apatite (HCA), (ii) to promote the delivery of Sr ions in defect areas, and (iii) to improve the secretion of angiogenic factors [193].

On the other hand, Luz et al. [195] developed chitosan/bioactive glass composites with Mg-containing bioactive glasses with enhanced cellular viability and higher ALP activity compared to chitosan/bioactive without $\mathrm{Mg}$ ions. As it is well known, $\mathrm{Mg}$ ion is not only a cofactor of enzymes that stabilize the structure of RNA and DNA [48,196], but it also influences the phenotype of osteogenic cells and has a pivotal role in the development of skeletal and in the remodeling of bone [107,197]. Furthermore, $\mathrm{Mg}$ increases the expression of type $X$ collagen and vascular endothelial growth factor (VEGF), and it increases cell spreading, cell proliferation, and ALP activity [85]. Additionally, chitosan/bioactive glasses with MgO, SrO (BGMS10 [38]), and ZnO (BGMS_2Zn [54]) showed higher cellular viability compared to the cellular viability of chitosan wound dressings [198].

Thus, composites with bioactive glass containing therapeutic ions could represent a promising application for both hard and soft tissues. However, in general, bioactive glasses containing or not some therapeutic ions (i.e., $\mathrm{Sr}, \mathrm{Mg}, \mathrm{Ag}, \mathrm{Zn}, \mathrm{Cu}$ ) are more bio-reactive and show higher capability in stimulating cellular response compared to chitosan matrix. Thus, cells preferentially adhered and proliferated in the area with bioactive glasses with respect to the chitosan area, as found in chitosan/bioactive glass $\left(\mathrm{SiO}_{2}: \mathrm{CaO}: \mathrm{P}_{2} \mathrm{O}_{5}=55: 40: 5 \mathrm{~mol} \%\right)$ composites developed by microcontact printing [199]. Higher cellular viability and a higher spreading of cells were also found on chitosan/bioactive glass scaffolds developed by Peter et al. [200]. On the contrary, chitosan/bioactive glass $\left(60 \mathrm{SiO}_{2}-36 \mathrm{CaO}-4 \mathrm{P}_{2} \mathrm{O}_{5} \mathrm{~mol} \%\right)$ foam developed by Martins et al. [201] did not show higher cell viability compared to pure chitosan foam. However, chitosan/bioactive glass foams showed improved mechanical behavior in terms of elastic modulus and shape recovery compared to chitosan foams. This can be attributed to the chemical crosslinking, which probably resulted from intermolecular reactions between carbonyl and amino groups of chitosan and the silanol group of bioactive glasses [201].

Table 5 summarizes chitosan/bioactive glass composites. 
Table 5. Summary of chitosan/bioactive glass composites for hard and soft tissue applications.

\begin{tabular}{|c|c|c|c|c|}
\hline Bioactive Glass & Technique & Composites' Characteristics & Applications & Ref. \\
\hline $\begin{array}{l}\mathrm{BG}\left(46.08 \mathrm{SiO}_{2}-22.96 \mathrm{Na}_{2} \mathrm{O}-\right. \\
\left.27.18 \mathrm{CaO}-3.77 \mathrm{P}_{2} \mathrm{O}_{5} \mathrm{wt} \%\right)\end{array}$ & Solvent casting & $\begin{array}{c}\text { Water contact angle chitosan/bioactive } \\
\text { glass microparticles }(\mathrm{CS} / \mu \mathrm{BG}) \text { control } \\
=7.45 \pm 6.5^{\circ}, \mathrm{CS} / \mu \mathrm{BG} 7 \mathrm{~d} \text { in PBS }=86.4 \\
\pm 6.5^{\circ} ; \text { chitosan/bioactive glass } \\
\text { nanoparticles }(\mathrm{CS} / \mathrm{nBG}) \text { control }=65.0 \\
\pm 6.3^{\circ}, \mathrm{CS} / \mathrm{nBG} 7 \mathrm{~d} \text { in } \mathrm{PBS}=81.2 \pm \\
14.6^{\circ} ; \text { Young's Modulus } \mathrm{CS} / \mu \mathrm{BG}=17 \\
\mathrm{MPa} \text {, Young's Modulus } \mathrm{CS} / \mathrm{nBG}=20 \\
\text { MPa. Excellent hydroxyapatite } \\
\text { forming ability }\end{array}$ & $\begin{array}{l}\text { Membranes } \\
\text { for bone } \\
\text { regeneration }\end{array}$ & [164] \\
\hline $55 \mathrm{SiO}_{2}-40 \mathrm{CaO}-5 \mathrm{P}_{2} \mathrm{O}_{5} \mathrm{~mol} \%$ & $\begin{array}{l}\text { Dispensing the } \\
\text { precursor } \\
\text { solutions in } \\
\text { wettable spots } \\
\text { previously } \\
\text { patterned onto } \\
\text { superhydrophobic } \\
\text { surfaces }\end{array}$ & $\begin{array}{l}\text { Storage modulus }=0.03-5 \mathrm{MPa} \text {. } \\
\text { Enhanced proliferation and spreading } \\
\text { of pre-osteoblast cell line with a } \\
\text { fibroblast-like phenotype (MC3T3-E1) }\end{array}$ & $\begin{array}{l}\text { Hydrogels for } \\
\text { bone tissue } \\
\text { engineering }\end{array}$ & [165] \\
\hline $\mathrm{BG}\left(55 \mathrm{SiO}_{2}-40 \mathrm{CaO}-5 \mathrm{P}_{2} \mathrm{O}_{5} \mathrm{~mol} \%\right)$ & Mixing solution & $\begin{array}{c}\text { BG nanoparticles: } 0 \% \text { (control), } 10 \% \text {, } \\
20 \%, 30 \%, 40 \% \text { and } 50 \% \\
(\mathrm{wBG} / \text { wchitosan) } \\
\text { Storage modulus: BG10=24.1 Pa, } \\
\text { BG20 = 76.2 Pa, BG30 = 65.0 Pa, BG40 } \\
=105.2 \mathrm{~Pa}, \mathrm{BG} 50=107.2 \mathrm{~Pa} \text {. Loss } \\
\text { modulus: BG10 = 17.0 Pa, BG20 = } \\
\text { 19.8 Pa, BG30 }=16.7 \mathrm{~Pa}, \mathrm{BG} 40=18.2 \\
\text { Pa, BG50 }=17.7 \mathrm{~Pa} . \\
\text { Gelation point BG10 }=38.3^{\circ} \mathrm{C}, \mathrm{BG} 20 \\
=29.3^{\circ} \mathrm{C}, \mathrm{BG} 30=37.0^{\circ} \mathrm{C}, \mathrm{BG} 40= \\
36.9^{\circ} \mathrm{C} ; \mathrm{BG} 50=36.8^{\circ} \mathrm{C}\end{array}$ & $\begin{array}{l}\text { Injectable } \\
\text { systems for } \\
\text { small bone } \\
\text { defects }\end{array}$ & [166] \\
\hline $60 \mathrm{SiO}_{2}-36 \mathrm{CaO}-4 \mathrm{P}_{2} \mathrm{O}_{5} \mathrm{~mol} \%$ & $\begin{array}{l}\text { Needle punching } \\
\text { process }\end{array}$ & $\begin{array}{c}\text { Porosity }(\%)=77.52 \pm 1.67 ; \text { water } \\
\quad \text { absorption }(\%)=58.89 \pm 7.3 ; \\
\text { compression strength }=7.68 \pm 0.38 \\
\text { MPa; elastic modulus }=0.46 \pm 0.02 \\
\text { GPa; flexure strength }=6.0 \pm 0.4 \mathrm{MPa} \text {, } \\
\text { flexure modulus }=102.0 \pm 10 \mathrm{MPa} ; \\
\text { tensile strength }=3.11 \pm 0.24 \mathrm{MPa} \\
\text { tensile modulus }=196.0 \pm 17.0 \mathrm{MPa} \\
\text { fracture toughness }=0.24 \pm 0.02 \mathrm{MPa} \\
\mathrm{m}^{1 / 2} \text {. Good biocompatibility }\end{array}$ & $\begin{array}{l}\text { Scaffolds for } \\
\text { bone tissue } \\
\text { engineering }\end{array}$ & [167] \\
\hline $\begin{array}{c}6 \mathrm{Na}_{2} \mathrm{O}-8 \mathrm{~K}_{2} \mathrm{O}-8 \mathrm{MgO}- \\
22 \mathrm{CaO}-54 \mathrm{~B}_{2} \mathrm{O}_{3}-2 \mathrm{P}_{2} \mathrm{O}_{5} \mathrm{~mol} \%\end{array}$ & $\begin{array}{l}\text { Mixing chitosan } \\
\text { solution and } \\
\text { glass particles }\end{array}$ & $\begin{array}{c}\text { Injectability }=84-97 \% \text {; compressive } \\
\text { strength = 8-32 } \mathrm{MPa} \text {; density }=2-3 \\
\mathrm{gcm}^{-3} ; \text { disintegration resistance }= \\
90-95 \% \text {. Enhanced proliferation and } \\
\text { ALP activity; in vivo stimulation of } \\
\text { new bone formation }\end{array}$ & $\begin{array}{l}\text { Injectable } \\
\text { systems for } \\
\text { healing bone } \\
\text { defects }\end{array}$ & [168] \\
\hline $\begin{array}{c}\mathrm{BG}-\mathrm{NPs}\left(55 \mathrm{SiO}_{2}-40 \mathrm{CaO}-5 \mathrm{P}_{2} \mathrm{O}_{5}\right. \\
\text { mol } \%) \text {, where NPs means } \\
\text { nanoparticles }\end{array}$ & $\begin{array}{l}\text { Freeze-drying } \\
\text { technique }\end{array}$ & $\begin{array}{l}\text { Maximum swelling reached for } 100 \\
\text { vol } \% \text { of water }=358 \% \text {; Young's } \\
\text { Modulus }=55 \mathrm{kPa} \text {; strain recovery } \\
\text { under deformation strain } 30 \%= \\
10-80 \% \text {; shape fixity ratio }=98.2 \pm 0.7 \\
\text { and shape recovery ratio }=89.9 \pm 2.7 \\
\text { under deformation strain }=30 \% . \\
\text { Enhanced apatite formation in vitro }\end{array}$ & $\begin{array}{l}\text { Scaffolds for } \\
\text { bone tissue } \\
\text { engineering }\end{array}$ & [169] \\
\hline
\end{tabular}


Table 5. Cont.

\begin{tabular}{|c|c|c|c|c|}
\hline Bioactive Glass & Technique & Composites' Characteristics & Applications & Ref. \\
\hline $55 \mathrm{SiO}_{2}-40 \mathrm{CaO}-5 \mathrm{P}_{2} \mathrm{O}_{5} \mathrm{~mol} \%$ & Solvent casting & $\begin{array}{c}\text { Young's Modulus = } 2639 \pm 212 \mathrm{MPa} \\
\text { (dry), } 4.7 \pm 0.3 \mathrm{MPa}(\text { wet); ultimate } \\
\text { tensile strength }=49.6 \pm 9.2 \mathrm{MPa} \\
\text { (dry), } 3.3 \pm 0.6 \mathrm{MPa} \text { (wet); elongation } \\
\text { at break }=2.5 \pm 0.6 \% \text { (dry), } 71.6 \pm \\
11.6 \% \text { (wet); water uptake }=130 \pm 9 \% \text {. } \\
\text { Enhanced metabolic activity of } \\
\text { human periodontal ligament cells } \\
\text { (hPDL) and human bone marrow } \\
\text { stromal cells (hBMSC) }\end{array}$ & $\begin{array}{l}\text { Membranes } \\
\text { for guided } \\
\text { tissue } \\
\text { regeneration } \\
\text { (GTR) and } \\
\text { guided bone } \\
\text { regeneration } \\
\text { (GBR). }\end{array}$ & [170] \\
\hline $64 \mathrm{SiO}_{2}-31 \mathrm{CaO}-5 \mathrm{P}_{2} \mathrm{O}_{5} \mathrm{~mol} \%$ & Mixing solutions & $\begin{array}{l}\text { In vitro hydroxyapatite formation and } \\
\text { enhanced cell proliferation. In vivo } \\
\text { high rate of new bone regeneration }\end{array}$ & $\begin{array}{l}\text { Injectable } \\
\text { system for } \\
\text { bone } \\
\text { substitute }\end{array}$ & [184] \\
\hline $\begin{array}{c}55 \mathrm{SiO}_{2}-40 \mathrm{CaO}-5 \mathrm{P}_{2} \mathrm{O}_{5} \mathrm{~mol} \% \\
64 \mathrm{SiO}_{2}-26 \mathrm{CaO}-5 \mathrm{P}_{2} \mathrm{O}_{5}-5 \mathrm{MgO} \mathrm{mol} \%\end{array}$ & Solvent casting & $\begin{array}{l}\text { High hydrophilicity, good osteoblastic } \\
\text { response toward cellular } \\
\text { differentiation and mineralization }\end{array}$ & $\begin{array}{l}\text { Membranes } \\
\text { for guided } \\
\text { tissue } \\
\text { regeneration: } \\
\text { orthopedic } \\
\text { field }\end{array}$ & [195] \\
\hline $\begin{array}{c}\mathrm{BG} \_\mathrm{NPs}\left(55 \mathrm{SiO}_{2}-40 \mathrm{CaO}-5 \mathrm{P}_{2} \mathrm{O}_{5}\right. \\
\text { mol\%), where NPs means } \\
\text { nanoparticles }\end{array}$ & Solvent casting & $\begin{array}{l}\text { Nucleation and growth of apatite. } \\
\text { Density of cells on the patterned } \\
\text { substrate increased with increasing } \\
\text { culture time }\end{array}$ & $\begin{array}{l}\text { Membranes } \\
\text { pattern with } \\
\text { BG to } \\
\text { promote } \\
\text { guided tissue } \\
\text { regeneration } \\
\text { in the bone } \\
\text { side }\end{array}$ & [199] \\
\hline $\begin{array}{l}\text { Bioactive glass ceramic nanoparticles } \\
\text { (nBGCs) }\end{array}$ & $\begin{array}{l}\text { Lyophilization } \\
\text { technique }\end{array}$ & $\begin{array}{l}\text { Interconnected pores } 150-300 \mu \mathrm{m}, \\
\text { controlled swelling behavior, good } \\
\text { attachment and spread of cells }\end{array}$ & $\begin{array}{l}\text { Scaffolds for } \\
\text { tissue } \\
\text { applications }\end{array}$ & [200] \\
\hline $60 \mathrm{SiO}_{2}-36 \mathrm{CaO}-4 \mathrm{P}_{2} \mathrm{O}_{5} \mathrm{~mol} \%$ & Foaming method & $\begin{array}{l}\text { Young's modulus }=750 \pm 0.08 \mathrm{KPa} \text {; } \\
\text { compressive strength }=120 \pm 0.09 \\
\mathrm{KPa} \text {; toughness }=1936 \pm 0.07 \mathrm{KPa} \text {. } \\
\text { Total porosity }=65.0 \pm 3.6 \% \text {; average } \\
\text { pore size }=118.2 \pm 8.2 \mathrm{~mm} \text {; highly } \\
\text { interconnected pore system }=99.8 \pm \\
0.1 \% . \text { Increased swelling at low } \mathrm{pH} ; \\
\text { adequate cells viability }\end{array}$ & $\begin{array}{l}\text { Scaffolds for } \\
\text { tissue } \\
\text { regeneration } \\
\text { and } \\
\text { stimulation of } \\
\text { healing }\end{array}$ & [201] \\
\hline
\end{tabular}

\subsection{Alginate/Bioactive Glass Composites}

Alginate is typically derived from brown algae (Phaeophyceae; including aminaria hyperborean, laminaria digitate, laminaria japonica, ascophyllum nodosum, acrocystis pyrifera) through treatment with aqueous alkali solutions, usually $\mathrm{NaOH}$ [202-204]. Alginates are formed by (1-4) linked 
$\beta$-D-mannuronic acid ( $M$ units) and its C-5 epimer $\alpha$-L-guluronic acid ( $G$ units). The natural copolymer is a component found in algae such as kelp, and an exopolysaccharide found in bacteria (Pseudomonas aeruginosa). $M$ units and $G$ units interspersed with $M G$ sequences form alginates [205].

Even though alginate's structure is similar to that of an extracellular matrix (ECM), alginate is not degradable inside mammalians because of the absence of the alginate enzyme, which breaks the polymer chain. For this reason, the polymer chain should be partially oxidized with sodium periodate to make alginate degradable in a physiological environment [205]. Therefore, the alginate degradation rate depends especially on the oxidation degree, $\mathrm{pH}$, and temperature of the surrounding environment. Even though the biocompatibility of alginate is still under discussion for possible impurities due to the alginate extraction method [206], alginate is widely used in biomedical applications [204]. Its biocompatibility, biodegradability, hydrophilicity, and relatively low cost make alginate a suitable biomaterial for regenerative medicine [206-208]. Additionally, the capability of alginate to generate stable hydrogel in the presence of specific divalent or trivalent cations (i.e., $\mathrm{Ca}^{2+}, \mathrm{Sr}^{2+}, \mathrm{Al}^{3+}, \mathrm{Ga}^{3+}$ ) permits the fabrication of good scaffolds [209].

Alginate hydrogels have been previously used for cell encapsulation [210] and for vascular and cartilage regeneration [211,212]. Additionally, alginate can be dissolved in aqueous solutions without the aid of any solvents. In addition, alginate can be easily modified with peptides, proteins, and inorganic biomaterials. Therefore, alginate is a promising choice for allografts and autografts because alginate does not show the drawbacks such as morbidity and lengthening of the procedure during the process of harvesting [213].

Despite good properties, alginate exhibits poor mechanical strength, bioactivity, and osteoconductivity; thus, bioactive glasses can be combined to ameliorate the biological performance in terms of reactivity [214]. BGs affect the differentiation of osteoblast by increasing the level of ALP, osteocalcin, and osteopontin markers, which control genes involved in cell cycle and progression. Thus, these markers improve osteogenesis by controlling cells during progression toward mature osteoblasts [215]. Additionally, the osteogenesis and ALP activity are directly influenced by the releasing of $\mathrm{Si}, \mathrm{Ca}, \mathrm{Na}$, and $\mathrm{P}$ from the bioactive glass, which activate and upregulate gene expression in cells [216]. In this regard, a higher ALP activity was observed for nano bioactive glass ceramic/alginate scaffolds compared to pure alginate scaffolds [217]. Therefore, the incorporation of bioactive glass contributes to ALP activity, cell adhesion, and proliferation through the release of ions and the increase in the roughness of the composites' surface [218]. Furthermore, the addition of therapeutic ions could further improve the biological performances of composites, as already mentioned. Thus, 13-93 bioactive glass was used instead of $45 S 5$ to develop composite alginate 3D-printed scaffolds [219]. The addition of 13-93 enhanced the mechanical strength, the mineralization capability of apatite, and the cellular adhesion and differentiation of alginate/13-93 with respect to neat alginate scaffolds. The reason for the higher mechanical strength of alginate/13-93 was that bioactive glass particles showed a high surface area and nanopore volume [220]. The incorporation of 13-93 in alginate increased the $\mathrm{pH}$ of PBS, which favored ALP activity; it has been reported that optimum ALP activity occurs at $8.5 \mathrm{pH}$ during bone regeneration [221]. Furthermore, the releasing of $\mathrm{Mg}^{2+}$ and $\mathrm{SiO}^{4-}$ from 13-93 improved cells' attachment, proliferation, and differentiation [219]. Indeed, the Mg ion improves cellular proliferation and differentiation, and it has an important role in bone metabolism as well. $\mathrm{Mg}$ ions together with $\mathrm{Zn}$ ions promoted ALP activity, which stimulated bone metabolism [222]. In addition, the mechanical properties of BGs were improved by the addition of both $\mathrm{Mg}$ and $\mathrm{Zn}$ ions, because $\mathrm{Mg}-\mathrm{O}$ and $\mathrm{Zn}-\mathrm{O}$ bonds have higher bonding energy compared to Ca-O bonds [223].

Therefore, $\mathrm{Mg}$ and $\mathrm{Zn}$ containing bioactive glass were embedded in alginate to fabricate composite scaffolds with enhanced biological performance and ameliorated mechanical properties [224]. However, the incorporation of bioactive glass in an alginate matrix decreased the micro-porosity and increased the stiffness of alginate. The porosity of scaffolds should guarantee cell spreading and proliferation; thus, the average pore size should be around $100 \mu \mathrm{m}$ [225]. Even though the porosity decreased with increasing bioactive glass content, a greater cell viability and ALP activity on alginate/bioactive glass $\left(60 \mathrm{SiO}_{2}\right.$, 
$26 \mathrm{CaO}, 4 \mathrm{P}_{2} \mathrm{O}_{5}, 5 \mathrm{ZnO}$, and $5 \mathrm{MgO} \mathrm{mol} \%$ ) scaffolds compared to alginate scaffolds were detected [224]. This behavior could be due to the dissolution of ions that stimulate the formation of hydroxy carbonate apatite (HCA), which in turns stimulates osteogenic cell attachment and proliferation [226]. In this regard, Sr ions, which promote osteogenic and osteoblast differentiation, are usually added to bioactive glasses [227]. In fact, the $\mathrm{Sr}$ ion has been already employed as strontium ranelate in the treatment of osteoporosis due to its anabolic and anti-resorptive effect on bone [228]. Both Sr and $\mathrm{Zn}$ act as enhancers in bone formation, simultaneously decreasing bone resorption. The synergistic effect of $\mathrm{Sr}$ and $\mathrm{Zn}$ rebalances the bone turnover in favor of bone formation, resulting in an increased bone mass and strength [229].

Therefore, $\mathrm{Sr}$ and $\mathrm{Zn}$ containing bioactive glasses were used as fillers for alginate to improve both mechanical properties and in situ osseointegration [230,231]. The inclusions of bioactive glasses significantly increased the collapse stress/yield stress of the alginate/bioactive glass scaffolds compared to neat alginate scaffolds.

Furthermore, HCA mineralization improves the formation, growth, and maintenance of the tissue-scaffold interface [232,233]. During the immersion, the alkaline $\mathrm{pH}$ promotes cells to form new bone [221,234], while the alkaline products of bioactive glasses neutralize the products from alginate degradation [235]. In addition, bioactive glasses decrease the swelling properties of scaffolds because they decrease the polymers surface, which usually binds water molecules [236]. Indeed, the swelling capacity of alginate scaffolds decreased as much as the content of bioactive glasses increased [224,230]. Although it is proved that early swelling enhances cellular adhesion and growth $[237,238]$, a controlled swelling behavior is required for not compromising the mechanical properties of scaffolds [224]. Therefore, to retard and reduce the swelling behavior, alginate is usually crosslinked by bivalent cations such as $\mathrm{Ca}$ or $\mathrm{Sr}$, which bond with the carboxyl functional group of $\mathrm{G}$ units of the polymer chain [239]. The full crosslinking of alginate limits ions' availability, allowing control over the kinetics of gels. This is mainly provided by the inclusion of trivalent ions (i.e., $\mathrm{Al}^{3+}$ and $\mathrm{Ga}^{3+}$ ), which produce charge balancing and a tetrahedral structure. $\mathrm{Ga}^{3+}$ was also crosslinked with alginate in order to control gallium release [240] during degradation. Additionally, Ga/alginate composites showed higher compression strength compared to that measured for $\mathrm{Al} /$ alginate composites because $\mathrm{Ga}$ is expected to exhibit a higher degree of alginate crosslinking [241]. The compressive strength and elastic modulus increased with an increasing amount of gallium (Ga) in bioactive glass composition as in [242], and the reactive oxygen species (ROS) were reduced by Ga ions [243]. Furthermore, Ga showed an inhibition in bacteria growth [244]: the proposed mechanism is that Ga can disrupt the iron metabolism, increasing the vulnerability of the microorganisms because they are not able to distinguish between $\mathrm{Fe}^{3+}$ and $\mathrm{Ga}^{3+}$ where the former is redox active and the latter is redox inactive [244]. Therefore, the incorporation of Ga can be used to prevent possible bactericidal colonization of tissue engineering scaffolds after implantation.

On the other hand, a novel combination of glass nanoparticles and alginate to achieve a tunable release capability of $\mathrm{Ca}^{2+}[245]$ and $\mathrm{Ca}^{2+}$ together with $\mathrm{Cu}^{2+}$ were developed [246]. The release of $\mathrm{Ca}^{2+}$ and $\mathrm{Cu}^{2+}$ enhance cellular growth and differentiation. Such ions stimulated rat bone marrow-derived mesenchymal stem cells (rBMSCs) differentiation toward the osteogenic lineage and improve human umbilical vein endothelial cells (HUVEC) proliferation and vascular endothelial growth factor (VEGF) secretion [246]. Indeed, it is known that $\mathrm{Ca}^{2+}$ ions stimulate the differentiation of bone cells, the proliferation of osteoblasts, and the mineralization and metabolism of bone tissue $[87,187,188]$. On the other hand, $\mathrm{Cu}^{2+}$ ions play a pivotal role in bone vessel growth [247-249] and in the proliferation of endothelial cells $[250,251]$, being also a natural antimicrobial element [252] showing a synergistic antimicrobial effect with $\mathrm{Ca}^{2+}$ [253].

Table 6 summarizes alginate/bioactive glass composites. 
Table 6. Summary of alginate/bioactive glass composites for biomedical applications.

\begin{tabular}{|c|c|c|c|c|}
\hline Bioactive Glass & Technique & Composites' Characteristics & Applications & Ref. \\
\hline Biosilicate $^{\circledR}$ & Manual mixing & $\begin{array}{c}\text { Injectability time }=198-119 \mathrm{~s} \text {; storage } \\
\text { modulus }=10-77 \mathrm{kPa} \text {. Cell viability }= \\
\text { 800RFU }\end{array}$ & $\begin{array}{l}\text { Injectable } \\
\text { systems for } \\
\text { bone } \\
\text { regenerative }\end{array}$ & [209] \\
\hline $80 \mathrm{SiO}_{2}-15 \mathrm{CaO}-5 \mathrm{P}_{2} \mathrm{O}_{5} \mathrm{~mol} \%$ & $\begin{array}{l}\text { Self-crosslinking } \\
\text { process }\end{array}$ & $\begin{array}{c}\text { Porosity }=60-75 \% \text {; compressive } \\
\text { strength }=0.3-2.5 \mathrm{MPa} \text {; compressive } \\
\text { modulus }=5-65 \mathrm{MPa} \text {. Relatively } \\
\text { excellent apatite formation ability } \\
\text { in vitro. Promotion of early cell } \\
\text { adhesion }\end{array}$ & $\begin{array}{l}\text { Scaffolds for } \\
\text { bone } \\
\text { regeneration }\end{array}$ & [216] \\
\hline $\begin{array}{c}\mathrm{CaO}-\mathrm{SiO}_{2}-\mathrm{P}_{2} \mathrm{O}_{5} \text { nano bioactive glass } \\
\text { ceramic particles (nBGC) }\end{array}$ & $\begin{array}{l}\text { Lyophilization } \\
\text { technique }\end{array}$ & $\begin{array}{c}\text { Pore size } 100-300 \mu \mathrm{m} \text {; swelling ability; } \\
\text { limited degradation; enhanced } \\
\text { biomineralization. Good protein } \\
\text { adsorption; good cell attachment; } \\
\text { good cell proliferation }\end{array}$ & $\begin{array}{l}\text { Scaffolds for } \\
\text { periodontal } \\
\text { tissue } \\
\text { regeneration }\end{array}$ & [217] \\
\hline Mesoporous bioactive glass (MBG) & 3D plotting & $\begin{array}{c}\text { Pore size }=190-415 \mu \mathrm{m} \text {; porosity }= \\
50-69 \% \text {; compressive strength }= \\
0.4-1.6 \mathrm{MPa} \text {; compressive modulus }= \\
\text { 1.5-6 MPa. Increased apatite } \\
\text { mineralization and cytocompatibility }\end{array}$ & $\begin{array}{l}\text { Scaffolds for } \\
\text { bone tissue } \\
\text { engineering }\end{array}$ & [218] \\
\hline 13-93 BG & 3D printing & $\begin{array}{c}\text { Pore size }=250-500 \mu \mathrm{m} \text {; porosity }= \\
65-87 \% \text {; compressive strength = } \\
9-16 \mathrm{MPa} \text {; modulus }=40-80 \mathrm{MPa} \text {. } \\
\text { Increased apatite mineralization; rat } \\
\text { bone mesenchymal stem cells } \\
\text { (rBMSC) spread, } \\
\text { adhere and improved osteogenical } \\
\text { differentiation }\end{array}$ & - & [219] \\
\hline $\begin{array}{c}60 \mathrm{SiO}_{2}-26 \mathrm{CaO}-4 \mathrm{P}_{2} \mathrm{O}_{5}-5 \mathrm{ZnO}-5 \mathrm{MgO} \\
\mathrm{mol} \%\end{array}$ & $\begin{array}{l}\text { Freeze-drying } \\
\text { technique }\end{array}$ & $\begin{array}{c}\text { Pore size }=75-275 \mu \mathrm{m} \text {; compressive } \\
\text { strength }=0.2-1.7 \mathrm{MPa} \text {; elastic } \\
\text { modulus }=3.5-18 \mathrm{MPa} \text {; toughness }= \\
0.25-0.75 \mathrm{MJ} / \mathrm{m}^{3} \text {. Improved } \\
\text { degradation rate; improved HA } \\
\text { formation; good MG-63 cell line } \\
\text { (CRL-1427, } 14 \text { years, Caucasian, } \\
\text { Passage } 4 \text { ) response (viability, } \\
\text { attachment and proliferation); restrict } \\
\text { growth of both S. aureus and E. coli }\end{array}$ & $\begin{array}{l}\text { Scaffolds for } \\
\text { bone tissue } \\
\text { engineering }\end{array}$ & [224] \\
\hline $\begin{array}{c}\mathrm{A} 0 \\
\left(36.4 \mathrm{SiO}_{2}-6.0 \mathrm{P}_{2} \mathrm{O}_{5}-26.5 \mathrm{CaO}-2.2 \mathrm{CaF}_{2}-\right. \\
26.5 \mathrm{SrO}-2.2 \mathrm{SrF}_{2}-0 \mathrm{Na}_{2} \mathrm{O}-0 \mathrm{~K}_{2} \mathrm{O}-0 \mathrm{ZnO} \\
\left.\mathrm{mol}^{2}\right) ; \\
\mathrm{A} 1 \\
\left(44.0 \mathrm{SiO}_{2}-5.0 \mathrm{P}_{2} \mathrm{O}_{5}-15.0 \mathrm{CaO}-0 \mathrm{CaF}_{2}\right. \\
-15.0 \mathrm{SrO}-0 \mathrm{SrF}_{2}-10.0 \mathrm{Na}_{2} \mathrm{O}- \\
\left.10.0 \mathrm{~K}_{2} \mathrm{O}-1.0 \mathrm{ZnO} \mathrm{mol} \%\right)\end{array}$ & $\begin{array}{l}\text { Freeze-drying } \\
\text { technique }\end{array}$ & $\begin{array}{l}\text { Pore size }=100-133 \mu \mathrm{m} ; \text { Young's } \\
\quad \text { Modulus }=1.6-2.8 \mathrm{MPa}\end{array}$ & $\begin{array}{l}\text { Scaffolds for } \\
\text { bone } \\
\text { applications }\end{array}$ & [230] \\
\hline 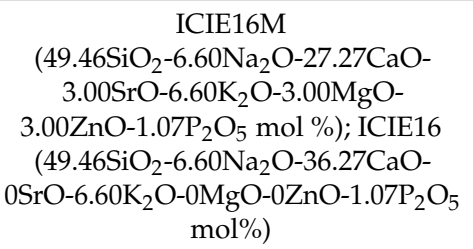 & $\begin{array}{l}\text { Freeze-drying } \\
\text { technique }\end{array}$ & $\begin{array}{c}\text { Average pore size of } 110 \mu \mathrm{m} \text { and } \\
\text { maximum pore size of } 309 \mu \mathrm{m} ; \\
\text { average collapse stress/yield stress }= \\
0.175 \pm 0.04 \mathrm{MPa} \text {; average Young's } \\
\text { Modulus }=1.83 \pm 0.66 \mathrm{MPa}\end{array}$ & $\begin{array}{l}\text { Scaffolds for } \\
\text { bone } \\
\text { applications }\end{array}$ & [231] \\
\hline
\end{tabular}


Table 6. Cont.

\begin{tabular}{|c|c|c|c|c|}
\hline Bioactive Glass & Technique & Composites' Characteristics & Applications & Ref. \\
\hline 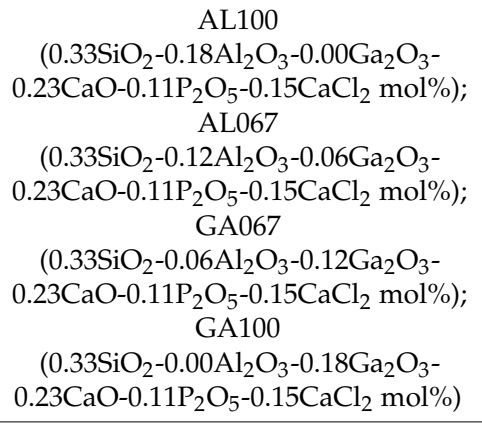 & $\begin{array}{l}\text { Mixing } \\
\text { solutions }\end{array}$ & $\begin{array}{l}\text { Ultimate compressive strength }= \\
10-70 \mathrm{kPa} \text {; elastic modulus }=70-340 \\
\mathrm{kPa} \text {. High biocompatibility }\end{array}$ & $\begin{array}{l}\text { Hydrogels } \\
\text { for } \\
\text { applications } \\
\text { in tissue } \\
\text { enginnering }\end{array}$ & [241] \\
\hline $46 \mathrm{SiO}_{2}-23 \mathrm{Na}_{2} \mathrm{O}-27 \mathrm{CaO}-4 \mathrm{P}_{2} \mathrm{O}_{5} \mathrm{wt} \%$ & $\begin{array}{l}\text { Solvent casting, } \\
\text { drying and } \\
\text { crosslinking } \\
\text { technique }\end{array}$ & $\begin{array}{l}\text { Young's modulus }=0.3-1.45 \mathrm{GPa} \text {. } \\
\text { Improved acellular bioactivity; } \\
\text { enhanced osteoblast-like cell } \\
\text { proliferation }\end{array}$ & $\begin{array}{l}\text { Films with } \\
\text { prophylaxis } \\
\text { effect against } \\
\text { infections } \\
\text { and } \\
\text { potential use } \\
\text { in bone } \\
\text { tissue } \\
\text { engineering }\end{array}$ & [244] \\
\hline $45 S 5$ & Solvent casting & $\begin{array}{l}\text { Tensile strength }=7 \mathrm{MPa} \text {. Improved } \\
\text { biomineralization in vitro }\end{array}$ & $\begin{array}{l}\text { Scaffolds for } \\
\text { bone tissue } \\
\text { engineering }\end{array}$ & [245] \\
\hline $\begin{array}{l}\text { Nbg: nominal composition close to } \\
\quad \text { Bioglass } 45 \mathrm{~S} 5 \\
\left(46 \mathrm{SiO}_{2}-27 \mathrm{CaO}-23 \mathrm{Na}_{2} \mathrm{O}-4 \mathrm{P}_{2} \mathrm{O}_{5} \mathrm{wt} \%\right)\end{array}$ & $\begin{array}{l}\text { Solvent casting } \\
\text { and drying }\end{array}$ & $\begin{array}{l}\text { Ultimate strength = 6.5-7 MPa. } \\
\text { Enhanced bioactivity; stimulation of } \\
\text { rat bone marrow-derived } \\
\text { mesenchymal stem cells (rBMSCs) } \\
\text { differentiation; enhanced human } \\
\text { umbilical vein endothelial cells } \\
\text { (HUVEC) proliferation and vascular } \\
\text { endothelial growth factor (VEGF) } \\
\text { secretion }\end{array}$ & $\begin{array}{l}\text { Scaffolds for } \\
\text { bone tissue } \\
\text { engineering }\end{array}$ & [246] \\
\hline
\end{tabular}

\subsection{Cellulose/Bioactive Glass Composites}

Cellulose is the most abundant biopolymer in the biosphere, and it can be obtained from a broad range of plants and animals. Generally, cellulose is obtained from plant sources; however, it can be extracted from bacteria (i.e., bacterial cellulose). The monomer unit of cellulose ( $\beta$-D-anhydroglucopyranose) is connected covalently through acetal functions to another monomer unit ( $\beta-1,4$-glycosidic bonds). These $\beta-1,4$-glycosidic bonds guarantee the resistance of cellulose to chemical/enzymatic attack $[12,254]$. The degree of linearity and $-\mathrm{OH}$ groups in the cellulose structure drive the formation of intermolecular and intramolecular hydrogen bonds through the polymer chain [12]. The chains of cellulose are organized in parallel arrangements (i.e., crystalline regions and amorphous-like regions), which influence the physical and chemical properties of cellulose itself [254]. At least five allomorphic forms of cellulose exist: cellulose I, which is the one found in nature, and other crystal structures named cellulose II, III, and IV, where cellulose II is the most stable structure [12]. The three -OH groups in each glucose unit of cellulose influence its reactivity.

Anyways, cellulose has low solubility in common solvents and low dimensional stability, and it shows poor hydrophilicity, bioactivity, and antibacterial properties. Thus, a physical and/or chemical modification of cellulose is required [12].

In addition, bioactive glasses (BGs) can be added to the cellulose matrix to fabricate composites with improved bioactivity and biocompatibility. Cellulose nanofibrils/BG scaffolds with porous microstructure that are able to grow and regenerate bone were developed and investigated $[255,256]$. By combining cellulose with bioactive glasses, the two main drawbacks (i.e., cellulose bioactivity and bioactive glasses mechanical properties) found in the individual use of such materials could be 
surpassed. In this sense, the incorporation of $\mathrm{CuO}$ oxide, where the $\mathrm{Cu}$ ion is known as an essential participant in angiogenesis, could significantly affect the wound healing [255]. The incorporation of $\mathrm{CuO}$ did not influence negatively the in vitro mineralization; samples were covered by a hydroxycarbonate apatite (HCA) layer after being soaked in SBF [255,256]. Additionally, the rough surface of HCA favors cell functions in tissue engineering. Such roughness resulted similar to that of cellulose/bioactive glass scaffolds (CC-Bio). These CC-Bio stimulated differentiation into osteoblastic lineage and bone formation [256].

The morphology of the surface in contact with the host tissue is as important as the chemistry of the surface and its capability to release specific ions. For this reason, the surface of metallic devices has been modified with bioactive materials to prevent or postpone second surgeries. The aim was to improve the bone-to-implant contact, reducing infections and surface corrosion.

Cellulose matrix embedding bioactive glasses are considered a promising alternative to conventional bio-ceramic coatings (e.g., [257,258]). The use of cellulose (i) enhances the bond at the interface of surface-devices, (ii) improves the strength of the coatings, (iii) and reduces the releasing rate of ions from bio-ceramic materials. Cellulose nanocrystal (CNC) and bioactive glass coatings on 316L stainless steel by a one-step electrophoretic deposition (EPD) process were fabricated as an alternative to conventional coatings $[259,260]$. Cellulose acted as a binder, strengthening the connection between the substrate and coatings, leading to a more stable adhesion. The coatings preserved their porous structure as assessed by contact angle measurement [260] and showed higher roughness with respect to the surface of the implant. On the other hand, BGs accelerated the mineralization on the surface of the coatings $[259,260]$ as well as ALP activity, which is the marker of increased bone formation [259].

Table 7 summarizes alginate/bioactive glass composites.

Table 7. Summary of cellulose/bioactive glass composites for biomedical applications.

\begin{tabular}{|c|c|c|c|c|}
\hline Bioactive Glass & Technique & $\begin{array}{c}\text { Composites' } \\
\text { Characteristics }\end{array}$ & Applications & Ref. \\
\hline $\begin{array}{c}\text { MBGSi80 (molar ratio Si/Ca/P = } \\
\text { 80/15/5); MBGSi78Cu2 (molar } \\
\text { ratio Si/Cu/Ca/P = 78/2/15/5); } \\
\text { MBGSi75Cu5 (molar ratio } \\
\mathrm{Si} / \mathrm{Cu} / \mathrm{Ca} / \mathrm{P}=75 / 5 / 15 / 5\end{array}$ & $\begin{array}{l}\text { Freeze-drying and } \\
\text { lyophilization } \\
\text { technique }\end{array}$ & $\begin{array}{l}\text { Angiogenic effect in the } \\
\text { angiogenesis assay; } \\
\text { enhanced the gene } \\
\text { expression }\end{array}$ & $\begin{array}{l}\text { Membranes for } \\
\text { wound healing } \\
\text { dressings }\end{array}$ & [255] \\
\hline BG & $\begin{array}{l}\text { Freeze-casting } \\
\text { technique }\end{array}$ & $\begin{array}{c}\text { Pore size }=135 \pm 33 \mu \mathrm{m} . \\
\text { Improved hydroxyapatite } \\
\text { formation; enhanced cellular } \\
\text { proliferation }\end{array}$ & $\begin{array}{l}\text { Scaffolds for bone } \\
\text { tissue engineering }\end{array}$ & [256] \\
\hline $45 \mathrm{~S} 5$ & $\begin{array}{l}\text { One step } \\
\text { electrophoretic } \\
\text { co-deposition } \\
\text { process }\end{array}$ & $\begin{array}{c}\text { Thickness }=28 \mu \mathrm{m} . \\
\text { Enhanced attachment, } \\
\text { proliferation, and } \\
\text { differentiation of cells; } \\
\text { accelerated mineralization } \\
\text { capability }\end{array}$ & $\begin{array}{l}\text { Hybrid coatings for } \\
\text { orthopedic implants }\end{array}$ & [259] \\
\hline $45 \mathrm{~S} 5$ & $\begin{array}{c}\text { One-step } \\
\text { electrophoretic } \\
\text { deposition process }\end{array}$ & $\begin{array}{c}\text { As-deposited thickness }= \\
14.0 \pm 0.9 \mu \mathrm{m} ; \text { after } 14 \mathrm{~d} \text { in } \\
\text { SBF thickness }=7.1 \pm 0.6 \mu \mathrm{m}\end{array}$ & $\begin{array}{c}\text { Coatings for } \\
\text { bio-functionalization } \\
\text { of metallic } \\
\text { orthopedic implants }\end{array}$ & [260] \\
\hline
\end{tabular}

\section{Additional Remarks}

Finally, natural polymers' advantages and disadvantages, due to their own properties, structure, and methods used to obtain them from natural sources, are summarized in Table 8. 
Table 8. Summary of respective advantages and disadvantages of natural polymers previously analyzed.

\begin{tabular}{|c|c|c|c|}
\hline Polymer & Advantages & Disadvantages & Refs. \\
\hline Collagen & $\begin{array}{l}\text { Biodegradable, biocompatible, } \\
\text { hemostatic, easily modifiable and } \\
\text { versatile. Compatible with } \\
\text { synthetic polymers }\end{array}$ & $\begin{array}{l}\text { Poor mechanical strength and } \\
\text { stiffness. } \\
\text { Variability of isolated collagen, } \\
\text { hydrophilicity }\end{array}$ & {$[12,73,261]$} \\
\hline Gelatin & $\begin{array}{c}\text { Biodegradable, biocompatible, } \\
\text { very low antigenicity, good cell } \\
\text { recognition }\end{array}$ & $\begin{array}{l}\text { Fast degradation rate in } \\
\text { physiological fluids, brittle }\end{array}$ & [12] \\
\hline Silk fibroin & $\begin{array}{l}\text { Biodegradable, biocompatible, } \\
\text { good structural stability, strength, } \\
\text { biodegradability, elasticity, low } \\
\text { tissue reactivity }\end{array}$ & $\begin{array}{l}\text { Lacks the potential to induce } \\
\text { osteogenesis, sericin needs to be } \\
\text { removed }\end{array}$ & {$[12,128]$} \\
\hline Hyaluronic acid & Biodegradable, biocompatible & $\begin{array}{c}\text { High risk of biological } \\
\text { contamination, high purification } \\
\text { costs }\end{array}$ & [142] \\
\hline Chitosan & $\begin{array}{l}\text { Biodegradable, biocompatible, } \\
\text { hemostatic, hydrophilicity, } \\
\text { antibacterial activity, its structure } \\
\text { allows specific modifications } \\
\text { without too many difficulties }\end{array}$ & $\begin{array}{l}\text { Long period for bone formation, } \\
\text { crosslinkers needed to maintain } \\
\text { the integrity of structure }\end{array}$ & [262] \\
\hline Alginate & $\begin{array}{c}\text { Biodegradable, } \\
\text { non-immunogenicity, } \\
\text { hydrophilicity, formation of gels } \\
\text { capable of encapsulating cells, } \\
\text { drugs and other biological entities, } \\
\text { relative low cost }\end{array}$ & $\begin{array}{l}\text { Biocompatibility under discussion } \\
\text { for possible impurities due to the } \\
\text { alginate extract, partial oxidation } \\
\text { required to make alginate } \\
\text { degradable in physiological } \\
\text { environment }\end{array}$ & {$[205,206]$} \\
\hline Cellulose & $\begin{array}{l}\text { Biodegradable, biocompatible, } \\
\text { most abundant }\end{array}$ & $\begin{array}{l}\text { Low dimensional stability, and it } \\
\text { showed poor hydrophilicity, } \\
\text { bioactivity, and antibacterial } \\
\text { properties }\end{array}$ & {$[12]$} \\
\hline
\end{tabular}

\section{Conclusions and Future Challenges}

The papers reported in this review have shown that collagen, gelatin, silk fibroin, hyaluronic acid, chitosan, alginate, and cellulose containing bioactive glasses represent interesting materials for biomedical devices, for both hard and soft tissue, not least because of their biocompatibility and non-toxicity. The addition of nano-sized and micro-sized bioactive glass particles has been shown to improve mechanical properties, to enhance bioactivity, and to promote the cells' viability, adhesion, proliferation, and differentiation. However, the strength and cellular response of composites could be compromised when the content of BGs overcome the threshold limit. An appropriate balance between bioactive glasses as filler and good mechanical properties should be considered while developing such composites. Indeed, the hydroxycarbonate apatite on the surface of bioactive glasses has a stimulatory role on the differentiation of stem cells toward osteoblast cells, especially when therapeutic ions are introduced [263]. Additionally, the incorporation of bioactive glasses offers a chance to adjust the elasticity of polymers and the cellular response. The elasticity of natural polymers represents a pivotal feature that affects the cellular response both in vitro and in vivo.

Overall, combining natural polymers with bioactive glass particles to produce composites for both hard and soft tissues can represent an efficient strategy to heal different damages of the body. Considering the in vitro behavior, further research involving the investigation of different cell lines needs to be considered, gaining more relevant data on the osteogenic, odontogenic, and angiogenic behavior of natural polymer composites. Furthermore, it is worth noting that preclinical studies in animals should be improved and become the focus of future studies. In addition, future studies should 
pay attention to investigate the most advantageous combination of natural polymers and bioactive glasses to achieve good mechanical and biological performances of composites.

Indeed, a better understanding of how specific properties of natural polymer/bioactive glass composites affect cells activation and behavior will allow the optimization of composite production with specific biological responses. Additionally, more investigations on the response induced by specific natural polymers once implanted should be done to further avoid an undesired reaction after implantation.

Figure 2 summarizes future challenges of natural polymer/bioactive glass composites.

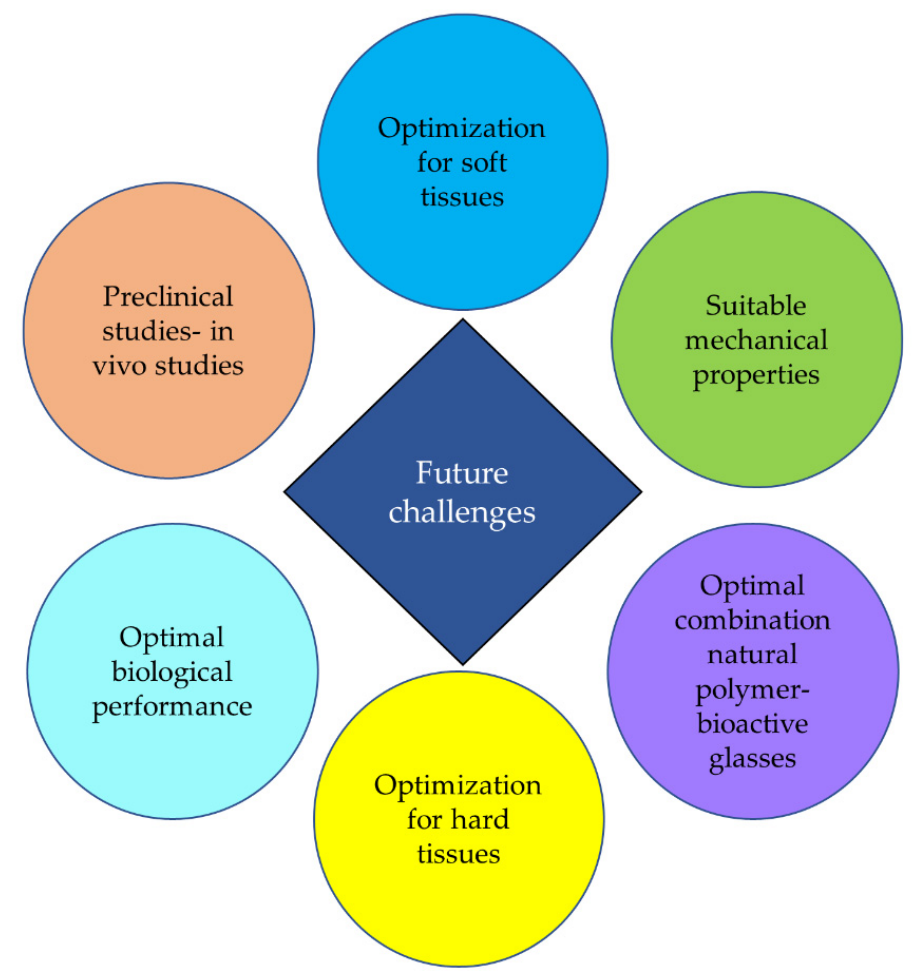

Figure 2. Future challenges.

Author Contributions: Investigation, writing-original draft preparation, R.S., D.B.; conceptualization, writing-review and editing, supervision, V.C. All authors have read and agreed to the published version of the manuscript.

Funding: This research received no external funding.

Conflicts of Interest: The authors declare no conflict of interest.

\section{References}

1. Linden, M.; Ray, D. Life expectancy effects of public and private health expenditures in OECD countries 1970-2012: Panel time series approach. Econ. Anal. Policy 2017, 56, 101-113. [CrossRef]

2. Vaupel, J.W. Biodemography of human ageing. Nature 2010, 464, 536-542. [CrossRef] [PubMed]

3. Daware, M.A. Review Article Osteoporosis in Elderly. Vidarbha. J. Intern. Med. 2014, 17, 19-27.

4. Lorentzon, M.; Cummings, S.R. Osteoporosis: The evolution of a diagnosis. J. Intern. Med. 2015, $277,650-661$. [CrossRef]

5. Hench, L.L. Biomaterials: A forecast for the future. Biomaterials 1998, 19, 1419-1423. [CrossRef]

6. Blackwood, D.J. Biomaterials: Past Successes and Future Problems. Corros. Rev. 2003, 21, 97-124. [CrossRef]

7. Pirhonen, E. Fibres and Composites for Potential Biomaterials Applications. Ph.D. Thesis, Tampere University of Technology, Tampere, Finland, 2006; pp. 1-84.

8. Hench, L.L.; Polak, J.M. Third-generation biomedical materials. Science 2002, 295, 1014-1017. [CrossRef] 
9. Griffith, L.G. Polymeric biomaterials. Acta Mater. 2000, 48, 263-277. [CrossRef]

10. Boccaccini, A.; Gough, J. Tissue Engineering Using Ceramics and Polymers; Woodhead Publishing Limited: Cambridge, UK, 2007; pp. 1-587.

11. Bhatia, S. Natural Polymer Drug Delivery Systems; Springer: Berlin/Heidelberg, Germany, 2016; pp. 1-225.

12. Kumbar, S.; Laurencin, C.; Deng, M. Natural and Synthetic Biomedical Polymers; Elsevier: Berlin/Heidelberg, Germany, 2014; pp. 1-402.

13. Sabu, T.; Neethu, N.; Sneha, M.; Elizabeth, F. Natural Polymers, Biopolymers, Biomaterials and Their Composites, Blends and IPNS; Apple Academic Press: Toronto, ON, Canada, 2012; pp. 1-407.

14. Kulkarni, V.; Butte, K.; Rathod, S. Natural Polymers-A Comprehensive Review. Int. J. Res. Pharm. Biomed. Sci. 2012, 3, 1597-1613.

15. Ratner, B.; Hoffman, A.; Schoen, F.; Lemons, J. Biomaterials Science an Introduction to Materials in Medicine, 2nd ed.; Elsevier: Amsterdam, The Netherlands, 2004; pp. 1-851.

16. Odian, G. Principles of Polymerization, 4th ed.; Odian, G., Ed.; Wiley Interscience a John Wiley \& Sons: Hoboken, NJ, USA, 2004; pp. 1-812.

17. Maitz, M.F. Applications of synthetic polymers in clinical medicine. Biosurface Biotribology 2015, 1, 161-176. [CrossRef]

18. Leite, A.; Mano, J. Biomedical applications of natural-based polymers combined with bioactive glass nanoparticles. J. Mater. Chem. B 2017, 5, 4555-4568. [CrossRef] [PubMed]

19. Marelli, B.; Ghezzi, C.E.; Barralet, J.E.; Boccaccini, A.R.; Nazhat, S.N. Three-dimensional mineralization of dense nanofibrillar collagen-bioglass hybrid scaffolds. Biomacromolecules 2010, 11, 1470-1479. [CrossRef] [PubMed]

20. Dziadek, M.; Stodolak-Zych, E.; Cholewa-Kowalska, K. Biodegradable ceramic-polymer composites for biomedical applications: A review. Mater. Sci. Eng. C 2017, 71, 1175-1191. [CrossRef]

21. Mano, J.F.; Silva, G.A.; Azevedo, H.S.; Sousa, P.B.; Sousa, R.A.; Silva, S.S.; Boesel, L.F.; Oliveira, J.M.; Santos, T.C.; Marques, A.P.; et al. Natural origin biodegradable systems in tissue engineering and regenerative medicine: Present status and some moving trends. J. R. Soc. Interface 2007, 4, 999-1030. [CrossRef] [PubMed]

22. Badylak, S.F. The extracellular matrix as a biologic scaffold material. Biomaterials 2007, 28, 3587-3593. [CrossRef]

23. D'Ayala, G.G.; Malinconico, M.; Laurienzo, P. Marine derived polysaccharides for biomedical applications: Chemical modification approaches. Molecules 2008, 13, 2069-2106. [CrossRef]

24. Klouda, L.; Mikos, A.G. Thermoresponsive hydrogels in biomedical applications-A review. Eur. J. Pharm. Biopharm. 2011, 68, 34-45. [CrossRef]

25. Araújo, M.; Viveiros, R.; Philippart, A.; Miola, M.; Doumett, S.; Baldi, G.; Perez, J.; Boccaccini, A.R.; Aguiar-Ricardo, A.; Verné, E. Bioactivity, mechanical properties and drug delivery ability of bioactive glass-ceramic scaffolds coated with a natural-derived polymer. Mater. Sci. Eng. C 2017, 768, 342-351. [CrossRef]

26. Harini, B.; Shadamarshan, R.P.K.; Rao, S.H.; Selvamurugan, N.; Balagangadharan, K. Natural and synthetic polymers/bioceramics/bioactive compounds-mediated cell signalling in bone tissue engineering. Int. J. Biol. Macromol. 2017, 110, 88-96.

27. Stanić, V. Variation in Properties of Bioactive Glasses after Surface Modification; Springer International Publishing AG: Berlin/Heidelberg, Germany, 2017; pp. 1-467.

28. Carvalho, S.M.; Moreira, C.D.F.; Oliveira, A.C.X.; Oliveira, A.A.R.; Lemos, E.M.F.; Pereira, M.M. Bioactive Glass Nanoparticles for Periodontal Regeneration and Applications in Dentistry Nanobiomaterials in Clinical Dentistry; Elsevier Inc.: Amsterdam, The Netherlands, 2019; pp. 351-383.

29. Ali, S.; Farooq, I.; Iqbal, K. A review of the effect of various ions on the properties and the clinical applications of novel bioactive glasses in medicine and dentistry. Saudi Dent. J. 2014, 26, 1-5. [CrossRef]

30. Profeta, A.C.; Prucher, G.M. Bioactive-glass in periodontal surgery and implant dentistry. Dent. Mater. J. 2015, 34, 559-571. [CrossRef] [PubMed]

31. Montazerian, M.; Zanotto, E.D. A guided walk through Larry Hench's monumental discoveries. J. Mater. Sci. 2017, 52, 8695-8732. [CrossRef]

32. Kokubo, T. Apatite formation on surfaces of ceramics, metals and polymers in body environment. Acta Mater. 1998, 46, 2519-2527. [CrossRef] 
33. Bellows, C.G.; Aubin, J.E.; Heersche, J.N.M. Initiation and progression of mineralization of bone nodules formed in vitro: The role of alkaline phosphatase and organic phosphate. Bone Miner. 1991, 14, 27-40. [CrossRef]

34. Hench, L.L. The story of Bioglass ${ }^{\circledR}$. J. Mater. Sci. Mater. Med. 2006, 17, 967-978. [CrossRef]

35. O'Donnell, M.D.; Hill, R.G.; Donnell, M.D.O. Influence of strontium and the importance of glass chemistry and structure when designing bioactive glasses for bone regeneration. Acta Biomater. 2010, 6, 2382-2385. [CrossRef]

36. Bellucci, D.; Sola, A.; Salvatori, R.; Anesi, A.; Chiarini, L.; Cannillo, V. Role of magnesium oxide and strontium oxide as modifiers in silicate-based bioactive glasses: Effects on thermal behaviour, mechanical properties and in-vitro bioactivity. Mater. Sci. Eng. C 2017, 72, 566-575. [CrossRef]

37. Aydin, H. Magnesium supplementation and bone. Magnes. Hum. Health Dis. 2013, 57, 149-157.

38. Bellucci, D.; Cannillo, V. A novel bioactive glass containing strontium and magnesium with ultra-high crystallization temperature. Mater. Lett. 2018, 213, 67-70. [CrossRef]

39. Bellucci, D.; Salvatori, R.; Anesi, A.; Chiarini, L.; Cannillo, V. SBF assays, direct and indirect cell culture tests to evaluate the biological performance of bioglasses and bioglass-based composites: Three paradigmatic cases. Mater. Sci. Eng. C 2019, 96, 757-764. [CrossRef]

40. Bellucci, D.; Salvatori, R.; Giannatiempo, J.; Anesi, A.; Bortolini, S.; Cannillo, V. A New Bioactive Glass/Collagen Hybrid Composite for Applications in Dentistry. Materials 2019, 12, 2079. [CrossRef] [PubMed]

41. Bellucci, D.; Veronesi, E.; Strusi, V.; Petrachi, T.; Murgia, A.; Mastrolia, I.; Dominici, M.; Cannillo, V. Human Mesenchymal Stem Cell Combined with a New Strontium-Enriched Bioactive Glass: An ex-vivo Model for Bone Regeneration. Materials 2019, 12, 3633. [CrossRef] [PubMed]

42. Elsayed, H.; Romero, A.R.; Bellucci, D.; Cannillo, V.; Bernardo, E. Advanced open-celled structures from low-temperature sintering of a crystallization-resistant bioactive glass. Materials 2019, 12, 3653. [CrossRef] [PubMed]

43. Bellucci, D.; Veronesi, E.; Dominici, M.; Cannillo, V. On the In vitro biocompatibility testing of bioactive glasses. Materials 2020, 13, 1816. [CrossRef] [PubMed]

44. Sergi, R.; Cannillo, V.; Boccaccini, A.R.; Liverani, L. Incorporation of bioactive glasses containing $\mathrm{Mg}$, $\mathrm{Sr}$ and $\mathrm{Zn}$ in electrospun PCL fibers by using benign solvents. Appl. Sci. 2020, 10, 5530. [CrossRef]

45. Di Tinco, R.; Sergi, R.; Bertani, G.; Pisciotta, A.; Bellucci, D.; Carnevale, G.; Cannillo, V.; Bertoni, L. Effects of a novel bioactive glass composition on biological properties of human dental pulp stem cells. Materials 2020, 13, 4049. [CrossRef]

46. Bellucci, D.; Veronesi, E.; Dominici, M.; Cannillo, V. A new bioactive glass with extremely high crystallization temperature and outstanding biological performance. Mater. Sci. Eng. C 2020, 110, 110699. [CrossRef]

47. Sergi, R.; Bellucci, D.; Salvatori, R.; Anesi, A.; Cannillo, V. A novel bioactive glass containing therapeutic ions with enhanced biocompatibility. Materials 2020, 13, 4600. [CrossRef]

48. Cacciotti, I. Bivalent cationic ions doped bioactive glasses: The influence of magnesium, zinc, strontium and copper on the physical and biological properties. J. Mater. Sci. 2017, 52, 8812-8831. [CrossRef]

49. Hoppe, A.; Güldal, N.S.; Boccaccini, A.R. A review of the biological response to ionic dissolution products from bioactive glasses and glass-ceramics. Biomaterials 2011, 32, 2757-2774. [CrossRef]

50. Balasubramanian, P.; Strobel, L.A.; Kneser, U.; Boccaccini, A.R. Zinc-containing bioactive glasses for bone regeneration, dental and orthopedic applications. Biomed. Glas. 2015, 1, 51-69. [CrossRef]

51. Huang, M.; Hill, R.G.; Rawlinson, S.C.F. Zinc bioglasses regulate mineralization in human dental pulp stem cells. Dent. Mater. 2017, 33, 543-552. [CrossRef] [PubMed]

52. Kim, Y. Antibacterial and remineralization effects of orthodontic bonding agents containing bioactive glass. Korean J. Orthod. 2018, 48, 163-171. [CrossRef] [PubMed]

53. Bari, A.; Bloise, N.; Fiorilli, S.; Novajra, G.; Vallet-Regí, M.; Bruni, G.; Torres-Pardo, A.; González-Calbet, J.M.; Visai, L.; Vitale-Brovarone, C. Copper-containing mesoporous bioactive glass nanoparticles as multifunctional agent for bone regeneration. Acta Biomater. 2017, 55, 493-504. [CrossRef]

54. Sergi, R.; Bellucci, D.; Salvatori, R.; Maisetta, G.; Batoni, G.; Cannillo, V. Zinc containing bioactive glasses with ultra-high crystallization temperature, good biological performance and antibacterial effects. Mater. Sci. Eng. C 2019, 104, 109910. [CrossRef] 
55. Nour, S.; Baheiraei, N.; Imani, R.; Rabiee, N.; Khodaei, M. Bioactive Materials: A Comprehensive Review on Interactions with Biological Microenvironment Based on the Immune Response. J. Bionic. Eng. 2019, 16, 563-581. [CrossRef]

56. Sengupta, D.; Heilshorn, S.C. Protein-engineered biomaterials: Highly tunable tissue engineering scaffolds. Tissue Eng. Part B Rev. 2010, 16, 285-293. [CrossRef]

57. Weiner, S.; Wagner, H.D. The material bone: Structure-mechanical function relations. Ann. Rev. Mater. Sci. 1998, 28, 271-298. [CrossRef]

58. Zhang, D.; Wu, X.; Chen, J.; Lin, K. The development of collagen based composite scaffolds for bone regeneration. Bioact. Mater. 2018, 3, 129-138. [CrossRef]

59. Ignatius, A.; Blessing, H.; Liedert, A.; Schmidt, C.; Neidlinger-Wilke, C.; Kaspar, D.; Friemert, B.; Claes, L. Tissue engineering of bone: Effects of mechanical strain on osteoblastic cells in type I collagen matrices. Biomaterials 2005, 26, 311-318. [CrossRef]

60. Geiger, M.; Li, R.H.; Friess, W. Collagen sponges for bone regeneration with rhBMP-2. Adv. Drug Deliv. Rev. 2003, 55, 1613-1629. [CrossRef] [PubMed]

61. Lutolf, M.P.; Weber, F.E.; Schmoekel, H.G.; Schense, J.C.; Kohler, T.; Müller, R.; Hubbell, J.A. Repair of bone defects using synthetic mimetics of collagenous extracellular matrices. Nat. Biotechnol. 2003, 21, 513-518. [CrossRef] [PubMed]

62. Guilak, F.; Cohen, D.; Estes, B.; Gimble, J.; Liedtke, W.; Chen, C. Control of stem cell fate by physical interactions with the extracellular matrix. Bone 2012, 23, 17-26. [CrossRef] [PubMed]

63. Prodanov, L.; te Riet, J.; Lamers, E.; Domanski, M.; Luttge, R.; van Loon, J.J.W.A.; Jansen, J.A.; Walboomers, X.F. The interaction between nanoscale surface features and mechanical loading and its effect on osteoblast-like cells behavior. Biomaterials 2010, 31, 7758-7765. [CrossRef]

64. Sundararaghavan, H.G.; Monteiro, G.A.; Firestein, B.L.; Shreiber, D.I. Neurite growth in 3D collagen gels with gradients of mechanical properties. Biotechnol. Bioeng. 2009, 102, 632-643. [CrossRef]

65. Ma, W.; Fitzgerald, W.; Liu, Q.Y.; O’Shaughnessy, T.J.; Maric, D.; Lin, H.J.; Alkon, D.L.; Barker, J.L. CNS stem and progenitor cell differentiation into functional neuronal circuits in three-dimensional collagen gels. Exp. Neurol. 2004, 190, 276-288. [CrossRef]

66. Law, J.X.; Liau, L.L.; Saim, A.; Yang, Y.; Idrus, R. Electrospun Collagen Nanofibers and Their Applications in Skin Tissue Engineering. Tissue Eng. Regen. Med. 2017, 14, 699-718. [CrossRef]

67. Sheehy, E.J.; Cunniffe, G.M.; O’Brien, F.J. Collagen-based biomaterials for tissue regeneration and repair. In Peptides and Proteins Biomaterials of Tissue Regeneration Repair; Elsevier: Duxford, UK, 2018; pp. 127-150.

68. Matsuno, T.; Nakamura, T.; Kuremoto, K.; Notazawa, S. Development of $\beta$-tricalcium Phosphate/Collagen Sponge Composite for Bone Regeneration. Dent. Mater. J. 2006, 25, 38-144. [CrossRef]

69. Zhang, Z.; Ma, Z.; Zhang, Y.; Chen, F.; Zhou, Y.; An, Q. Dehydrothermally crosslinked collagen/hydroxyapatite composite for enhanced in vivo bone repair. Colloids Surfaces B Biointerfaces 2018, 163, 394-401. [CrossRef]

70. Powell, H.M.; Supp, D.M.; Boyce, S.T. Influence of electrospun collagen on wound contraction of engineered skin substitutes. Biomaterials 2008, 29, 834-843. [CrossRef]

71. Chen, R.; Wang, G.; Chen, C.; Ho, H.; Sheu, M.-T. Development of N,O-(Carboxymethyl) chitosan/Collagen Matrixes as a Wound Dressing. Biomacromolecules 2006, 7, 1058-1064. [CrossRef] [PubMed]

72. Chen, J.P.; Chang, G.Y.; Chen, J.K. Electrospun collagen/chitosan nanofibrous membrane as wound dressing. Colloids Surfaces A Physicochem. Eng. Asp. 2008, 313, 183-188. [CrossRef]

73. Sarker, B.; Hum, J.; Nazhat, S.N.; Boccaccini, A.R. Combining collagen and bioactive glasses for bone tissue engineering: A review. Adv. Healthc. Mater. 2015, 4, 176-194. [CrossRef] [PubMed]

74. Cancedda, R.; Giannoni, P.; Mastrogiacomo, M. A tissue engineering approach to bone repair in large animal models and in clinical practice. Biomaterials 2007, 28, 4240-4250. [CrossRef] [PubMed]

75. Karageorgiou, V.; Kaplan, D. Porosity of 3D biomaterial scaffolds and osteogenesis. Biomaterials 2005, 26, 5474-5491. [CrossRef]

76. Shekaran, A.; Garcia, A. Extracellular matrix-mimetic adhesive biomaterials for bone repair. J. Biomed. Mater. Res. A 2012, 96, 261-272. [CrossRef]

77. Lanza, R.; Langer, R.; Vacanti, J. Principles of Tissue Engineering, 3rd ed.; Elsevier: Amsterdam, The Netherlands, 2007; pp. 1-1291. 
78. Long, T.; Yang, J.; Shi, S.S.; Guo, Y.P.; Ke, Q.F.; Zhu, Z.A. Fabrication of three-dimensional porous scaffold based on collagen fiber and bioglass for bone tissue engineering. J. Biomed. Mater. Res. Part B Appl. Biomater. 2015, 103, 1455-1464. [CrossRef]

79. Hong, S.J.; Yu, H.S.; Noh, K.T.; Oh, S.A.; Kim, H.W. Novel scaffolds of collagen with bioactive nanofiller for the osteogenic stimulation of bone marrow stromal cells. J. Biomater. Appl. 2010, 24, 733-750. [CrossRef]

80. Marelli, B.; Ghezzi, C.E.; Mohn, D.; Stark, W.J.; Barralet, J.E.; Boccaccini, A.R.; Nazhat, S.N. Accelerated mineralization of dense collagen-nano bioactive glass hybrid gels increases scaffold stiffness and regulates osteoblastic function. Biomaterials 2011, 32, 8915-8926. [CrossRef]

81. Rezwan, K.; Chen, Q.Z.; Blaker, J.J.; Boccaccini, A.R. Biodegradable and bioactive porous polymer/inorganic composite scaffolds for bone tissue engineering. Biomaterials 2006, 27, 3413-3431. [CrossRef]

82. Kim, H.-W.; Song, J.-H.; Kim, H.-E. Bioactive glass nanofiber-collagen nanocomposite as a novel bone regeneration matrix. J. Biomed. Mater. Res. 2006, 79, 698-705. [CrossRef] [PubMed]

83. Hattar, S.; Loty, S.; Gaisser, D.; Berdal, A.; Sautier, J.M. Effects of 58s sol-gel glasses on the temporal expression of bone markers during mouse osteoblastic differentiation. J. Biomed. Mater. Res. Part A 2006, 76, 811-819. [CrossRef] [PubMed]

84. Xynos, I.D.; Edgar, A.J.; Buttery, L.D.K.; Hench, L.L.; Polak, J.M. Ionic products of bioactive glass dissolution increase proliferation of human osteoblasts and induce insulin-like growth factor II mRNA expression and protein synthesis. Biochem. Biophys. Res. Commun. 2000, 276, 461-465. [CrossRef] [PubMed]

85. O'Neill, E.; Awale, G.; Daneshmandi, L.; Umerah, O.; Lo, K.W.H. The roles of ions on bone regeneration. Drug Discov. Today 2018, 23, 879-890. [CrossRef] [PubMed]

86. Dashnyam, K.; El-Fiqi, A.; Buitrago, J.O.; Perez, R.A.; Knowles, J.C.; Kim, H.W. A mini review focused on the proangiogenic role of silicate ions released from silicon-containing biomaterials. J. Tissue Eng. 2017, 8, 1-13. [CrossRef]

87. Maeno, S.; Niki, Y.; Matsumoto, H.; Morioka, H.; Yatabe, T.; Funayama, A.; Toyama, Y.; Taguchi, T.; Tanaka, J. The effect of calcium ion concentration on osteoblast viability, proliferation and differentiation in monolayer and 3D culture. Biomaterials 2005, 26, 4847-4855. [CrossRef]

88. Gao, X.; Wang, S.; Dong, Y.; Chen, X.; Gong, W. A novel nano-sized bioactive glass stimulates osteogenesis via the MAPK pathway. RSC Adv. 2017, 7, 13760-13767.

89. Humeau, J.; Bravo-San Pedro, J.M.; Vitale, I.; Nuñez, L.; Villalobos, C.; Kroemer, G.; Senovilla, L. Calcium signaling and cell cycle: Progression or death. Cell Calcium 2018, 70, 3-15. [CrossRef]

90. Allen-Durrance, A.E. A Quick Reference on Phosphorus. Vet. Clin. N. Am. Small Anim. Pract. 2017, 47, 257-262. [CrossRef]

91. Julien, M.; Khoshniat, S.; Lacreusette, A.; Gatius, M.; Bozec, A.; Wagner, E.F.; Wittrant, Y.; Masson, M.; Weiss, P.; Beck, L.; et al. Phosphate-dependent regulation of MGP in osteoblasts: Role of ERK1/2 and Fra-1. J. Bone Miner. Res. 2009, 24, 1856-1868. [CrossRef]

92. Wang, Y.; Xu, C.; Meng, Y.; Xiang, A.P.; Su, P.; Yu, W.; Xiang, A.P.; Wang, Y. Biocompatibility and osteogenesis of biomimetic Bioglass-Collagen-Phosphatidylserine composite scaffolds for bone tissue engineering. Biomaterials 2010, 32, 1051-1058.

93. Freyman, T.M.; Yannas, I.V.; Gibson, L.J. Cellular materials as porous scaffolds for tissue engineering. Prog. Mater. Sci. 2001, 46, 273-282. [CrossRef]

94. Naahidi, S.; Jafari, M.; Logan, M.; Wang, Y.; Yuan, Y.; Bae, H.; Dixon, B.; Chen, P. Biocompatibility of hydrogel-based scaffolds for tissue engineering applications. Biotechnol. Adv. 2017, 35, 530-544. [CrossRef] [PubMed]

95. Jafari, M.; Paknejad, Z.; Rad, M.R.; Motamedian, S.R.; Eghbal, M.J.; Nadjmi, N.; Khojasteh, A. Polymeric scaffolds in tissue engineering: A literature review. J. Biomed. Mater. Res. Part B Appl. Biomater. 2017, 105, 431-459. [CrossRef]

96. Eglin, D.; Maalheem, S.; Livage, J.; Coradin, T. In vitro apatite forming ability of type I collagen hydrogels containing bioactive glass and silica sol-gel particles. J. Mater. Sci. Mater. Med. 2006, 17, 161-167. [CrossRef]

97. Vargas, G.; Durand, L.; Cadena, V.; Romero, M.; Mesones, R.; Mackovic, M.; Spallek, S.; Spiecker, E.; Boccaccini, A.R.; Gorustovich, A.A. Effect of nano-sized bioactive glass particles on the angiogenic properties of collagen based composites. J. Mater. Sci. Mater. Med. 2013, 24, 1261-1269. [CrossRef] 
98. El-fiqi, A.; Ho, J.; Lee, E.; Kim, H. Collagen hydrogels incorporated with surface-aminated mesoporous nanobioactive glass: Improvement of physicochemical stability and mechanical properties is effective for hard tissue engineering. Acta Biomater. 2013, 9, 9508-9521. [CrossRef]

99. Heinemann, S.; Heinemann, C.; Jäger, M.; Neunzehn, J.; Wiesmann, H.P.; Hanke, T. Effect of silica and hydroxyapatite mineralization on the mechanical properties and the biocompatibility of nanocomposite collagen scaffolds. ACS Appl. Mater. Interfaces 2011, 3, 4323-4331. [CrossRef]

100. Desimone, M.F.; Hélary, C.; Rietveld, I.B.; Bataille, I.; Mosser, G.; Giraud-Guille, M.M.; Livage, J.; Coradin, T. Silica-collagen bionanocomposites as three-dimensional scaffolds for fibroblast immobilization. Acta Biomater. 2010, 6, 3998-4004. [CrossRef]

101. Zhou, T.; Sui, B.; Mo, X.; Sun, J. Multifunctional and biomimetic fish collagen/bioactive glass nanofibers: Fabrication, antibacterial activity and inducing skin regeneration In vitro and in vivo. Int. J. Nanomed. 2017, 12, 3495-3507. [CrossRef]

102. Ayuk, S.M.; Houreld, N.N.; Abrahamse, H. Collagen Production in Diabetic Wounded Fibroblasts in Response to Low-Intensity Laser Irradiation at $660 \mathrm{~nm}$. Diabetes Technol. Ther. 2012, 14, 1110-1117. [CrossRef] [PubMed]

103. Constantin, V.D.; Carap, A.; Bobic, S.; Budu, V.; Albu Kaya, M.; Marin, Ş.; Marin, M.M.; Socea, B. Tissue Engineering-Collagen Sponge Dressing for Chronic Wounds. In Proceedings of the ICAMS 2018 -7th International Conference on Advanced Materials and Systems, Bucharest, Romania, 18-20 October 2018; pp. 63-68.

104. Gorustovich, A.A.; Roether, J.A.; Boccaccini, A.R. Effect of Bioactive Glasses on Angiogenesis: A Review of In vitro and In vivo Evidences. Tissue Eng. Part B Rev. 2010, 16, 199-207. [CrossRef] [PubMed]

105. Li, H.; Chang, J. Bioactive silicate materials stimulate angiogenesis in fibroblast and endothelial cell co-culture system through paracrine effect. Acta Biomater. 2013, 9, 6981-6991. [CrossRef] [PubMed]

106. Oates, M.; Chen, R.; Duncan, M.; Hunt, J.A. The angiogenic potential of three-dimensional open porous synthetic matrix materials. Biomaterials 2007, 28, 3679-3686. [CrossRef] [PubMed]

107. Bose, S.; Tarafder, S.; Bandyopadhyay, A. Effect of Chemistry on Osteogenesis and Angiogenesis towards Bone Tissue Engineering Using 3D Printed Scaffolds. Ann. Biomed. Eng. 2017, 45, 261-272. [CrossRef]

108. Engler, A.J.; Sen, S.; Sweeney, H.L.; Discher, D.E. Matrix Elasticity Directs Stem Cell Lineage Specification. Cell 2006, 126, 677-689. [CrossRef]

109. Zandstra, P.W.; Discher, D.E.; Mooney, D.J. Growth Factors, Matrices, and Forces Combine and Control Stem Cells. Science 2009, 324, 1673-1677.

110. Discher, D.E.; Janmey, P.; Wang, Y.L. Tissue cells feel and respond to the stiffness of their environment. Science 2005, 10, 1139-1143. [CrossRef]

111. Zheng, J.; Zhao, F.; Zhang, W.; Mo, Y.; Zeng, L.; Li, X. Sequentially-crosslinked biomimetic bioactive glass/gelatin methacryloyl composites hydrogels for bone regeneration. Mater. Sci. Eng. C 2018, 89, $119-127$. [CrossRef]

112. Kazemi, M.; Azami, M.; Johari, B. Bone Regeneration in rat using a gelatin/bioactive glass nanocomposite scaffold along with endothelial cells (HUVECs). Int. J. Appl. Ceram. Technol. 2018, 15, 1427-1438. [CrossRef]

113. Kargozar, S.; Jafar, S.; Soleimani, M.; Brouki, P. Acceleration of bone regeneration in bioactive glass/gelatin composite scaffolds seeded with bone marrow-derived mesenchymal stem cells over-expressing bone morphogenetic protein-7. Mater. Sci. Eng. C 2017, 75, 688-698. [CrossRef] [PubMed]

114. Mozafari, M.; Moztarzadeh, F.; Rabiee, M.; Azami, M.; Nezafati, N.; Moztarzadeh, Z.; Tahriri, M. Development of $3 \mathrm{D}$ bioactive nanocomposite scaffolds made from gelatin and nano bioactive glass for biomedical applications. Adv. Compos. Lett. 2010, 19, 91-96. [CrossRef]

115. Mozafari, M.; Moztarzadeh, F.; Rabiee, M.; Azami, M. Development of macroporous nanocomposite scaffolds of gelatin/bioactive glass prepared through layer solvent casting combined with lamination technique for bone tissue engineering. Ceram. Int. 2010, 36, 2431-2439. [CrossRef]

116. Mozafari, M.; Rabiee, M.; Azami, M.; Maleknia, S. Biomimetic formation of apatite on the surface of porous gelatin/bioactive glass nanocomposite scaffolds. Appl. Surf. Sci. 2010, 257, 1740-1749. [CrossRef]

117. Gupta, N.; Santhiya, D. In situ mineralization of bioactive glass in gelatin matrix. Mater. Lett. 2017, 188, 127-129. [CrossRef]

118. Gao, C.; Gao, Q.; Li, Y.; Rahaman, M.N.; Teramoto, A.; Abe, K. In vitro Evaluation of Electrospun Gelatin-Bioactive Glass Hybrid Scaffolds for Bone Regeneration. J. Appl. Polym. Sci. 2013, 127, 2588-2599. [CrossRef] 
119. Lao, J.; Dieudonné, X.; Fayon, F.; Montouillout, V.; Jallot, E. Bioactive glass-gelatin hybrids: Building scaffolds with enhanced calcium incorporation and controlled porosity for bone regeneration. J. Mater. Chem. B 2016, 4, 2486-2497. [CrossRef]

120. Nadeem, D.; Kiamehr, M.; Yang, X.; Su, B. Fabrication and In vitro evaluation of a sponge-like bioactive-glass/gelatin composite scaffold for bone tissue engineering. Mater. Sci. Eng. C 2013, 33, 2669-2678. [CrossRef]

121. Gao, C.; Rahaman, M.N.; Gao, Q.; Teramoto, A.; Abe, K. Robotic deposition and In vitro characterization of 3D gelatin-bioactive glass hybrid scaffolds for biomedical applications. J. Biomed. Mater. Res. Part A 2013, 101, 2027-2037. [CrossRef]

122. Lacroix, J.; Jallot, E.; Lao, J. Gelatin-bioactive glass composites scaffolds with controlled macroporosity. Chem. Eng. J. 2014, 256, 9-13. [CrossRef]

123. Jalise, Z.S.; Bagheiraei, N.; Bagheri, F. The effects of strontium incorporation on a novel gelatin/bioactive glass bone graft: In vitro and in vivo characterization. Ceram. Int. 2018, 44, 14217-14227. [CrossRef]

124. Raz, M.; Moztarzadeh, F.; Kordestani, S.S. Sol-gel Based Fabrication and Properties of Mg-Zn Doped Bioactive Glass/Gelatin Composite Scaffold for Bone Tissue Engineering. Silicon 2018, 10, 667-674. [CrossRef]

125. Guo, W.; Zhao, F.; Wang, Y.; Tang, J.; Chen, X. Characterization of the mechanical behaviors and bioactivity of tetrapod $\mathrm{ZnO}$ whiskers reinforced bioactive glass/gelatin composite scaffolds. J. Mech. Behav. Biomed. Mater. 2017, 68, 8-15. [CrossRef] [PubMed]

126. Yazdimamaghani, M.; Vashaee, D.; Assefa, S.; Walker, K.J.; Madihally, S.V.; Köhler, G.A.; Tayebi, L. Hybrid Macroporous Gelatin/Bioactive-Glass/Nanosilver Scaffolds with Controlled Degradation Behavior and Antimicrobial Activity for Bone Tissue Engineering. J. Biomed. Nanotechnol. 2014, 10, 911-931. [CrossRef] [PubMed]

127. Zheng, K.; Wu, J.; Li, W.; Dippold, D.; Wan, Y.; Boccaccini, A.R. Incorporation of Cu-Containing Bioactive Glass Nanoparticles in Gelatin-Coated Sca ff olds Enhances Bioactivity and Osteogenic Activity. ACS Biomater. Sci. Eng. 2018, 4, 1546-1557.

128. Kundu, B.; Rajkhowa, R.; Kundu, S.C.; Wang, X. Silk fibroin biomaterials for tissue regenerations. Adv. Drug Deliv. Rev. 2013, 65, 457-470. [CrossRef]

129. Koh, L.-D.; Yu, H.-D.; Han, M.-Y.; Teng, C.-P.; Zhang, Y.-W.; Khin, Y.-W.; Loh, X.-J.; Tee, S.-Y.; Low, M.; Ye, E.; et al. Structures, mechanical properties and applications of silk fibroin materials. Prog. Polym. Sci. 2015, 46, 86-110. [CrossRef]

130. Thurber, A.E.; Omenetto, F.G.; Kaplan, D.L. In vivo bioresponses to silk proteins. Biomaterials 2015, 71, 145-157. [CrossRef]

131. Melke, J.; Midha, S.; Ghosh, S.; Ito, K.; Hofmann, S. Silk fibroin as biomaterial for bone tissue engineering. Acta Biomater. 2016, 31, 1-16. [CrossRef]

132. Ma, D.; Wang, Y.; Dai, W. Silk fibroin-based biomaterials for musculoskeletal tissue engineering. Mater. Sci. Eng. C 2018, 89, 456-469. [CrossRef]

133. Farokhi, M.; Mottaghitalab, F.; Fatahi, Y.; Khademhosseini, A.; Kaplan, D.L. Overview of Silk Fibroin Use in Wound Dressings. Trends Biotechnol. 2018, 36, 907-922. [CrossRef] [PubMed]

134. Du, X.; Wei, D.; Huang, L.; Zhu, M.; Zhang, Y.; Zhu, Y. 3D printing of mesoporous bioactive glass/silk fibroin composite scaffolds for bone tissue engineering. Mater. Sci. Eng. C 2019, 103, 109731. [CrossRef] [PubMed]

135. Wu, C.; Zhang, Y.; Zhou, Y.; Fan, W.; Xiao, Y. A comparative study of mesoporous glass/silk and non-mesoporous glass/silk scaffolds: Physiochemistry and in vivo osteogenesis. Acta Biomater. 2011, 7, 2229-2236. [CrossRef] [PubMed]

136. Shen, X.; Yu, P.; Chen, H.; Wang, J.; Lu, B.; Cai, X. Icariin controlled release on a silk fibroin/mesoporous bioactive glass nanoparticles scaffold for promoting stem cell osteogenic differentiation. RSC Adv. 2020, 10, 12105-12112. [CrossRef]

137. Moses, J.C.; Nandi, S.K.; Mandal, B.B. Multifunctional Cell Instructive Silk-Bioactive Glass Composite Reinforced Scaffolds Toward Osteoinductive, Proangiogenic, and Resorbable Bone Grafts. Adv. Healthc. Mater. 2018, 7, 1701418. [CrossRef]

138. Joseph, M.C.; Reardon, P.J.T.; Konwarh, R.; Knowles, J.C.; Mandal, B.B. Mimicking Hierarchical Complexity of the Osteochondral Interface Using Electrospun Silk-Bioactive Glass Composites. ACS Appl. Mater. Interfaces 2017, 9, 8000-8013. 
139. Bidgoli, M.; Tamjid, E.; Khafaji, M.; Alemzadeh, I.; Vossoughi, M. Fabrication of hierarchically porous silk fibroin-bioactive glass composite scaffold via indirect 3D printing: Effect of particle size on physicomechanical properties and in vitro cellular behavior. Mater. Sci. Eng. C 2019, 103, 109688. [CrossRef]

140. Zhu, H.; Liu, N.; Feng, X.; Chen, J. Fabrication and characterization of silk fibroin/bioactive glass composite films. Mater. Sci. Eng. C 2012, 32, 822-829. [CrossRef]

141. Rubert, M.; Alonso-Sande, M.; Monjo, M.; Ramis, J.M. Evaluation of alginate and hyaluronic acid for their use in bone tissue engineering. Biointerphases 2012, 7, 44. [CrossRef]

142. Fallacara, A.; Baldini, E.; Manfredini, S.; Vertuani, S. Hyaluronic acid in the third millennium. Polymers 2018, 10, 701. [CrossRef]

143. Boeriu, C.G.; Springer, J.; Kooy, F.K.; van den Broek, L.A.M.; Eggink, G. Production Methods for Hyaluronan. Int. J. Carbohydr. Chem. 2013, 624967. [CrossRef]

144. Liu, H.; Li, H.; Cheng, W.; Yang, Y.; Zhu, M.; Zhou, C. Novel injectable calcium phosphate/chitosan composites for bone substitute materials. Acta Biomater. 2006, 2, 557-565. [CrossRef] [PubMed]

145. Wang, X.; Chen, L.; Xiang, H.; Ye, J. Influence of Anti-Washout Agents on the Rheological Properties and Injectability of a Calcium Phosphate Cement. J. Biomed. Mater. Res. Part B Appl. Biomater. 2007, 81B, 410-418. [CrossRef] [PubMed]

146. Wu, L.; Zhu, F.; Tao, G. In-Vitro Biocompatibility Evaluation of Collagen-Hyaluronic Acid/Bioactive Glass Nanocomposite Scaffold. J. Macromol. Sci. Part A 2013, 50, 1121-1125. [CrossRef]

147. Zhou, Z.; He, S.; Ou, B.; Huang, T.; Zeng, W.; Liu, L.; Liu, Q.; Chen, J.; Zhao, Y.; Yang, Z.; et al. Influence of Nano-Bioactive Glass (NBG) content on properties of gelatin-hyaluronic acid/NBG composite scaffolds. J. Macromol. Sci. Part B Phys. 2014, 53, 1145-1155. [CrossRef]

148. Lou, J.; Stowers, R.; Nam, S.; Xia, Y.; Chaudhuri, O. Stress relaxing hyaluronic acid-collagen hydrogels promote cell spreading, fiber remodeling, and focal adhesion formation in 3D cell culture. Biomaterials 2018, 154, 213-222. [CrossRef] [PubMed]

149. Mohan, N.; Mohanan, P.V.; Sabareeswaran, A.; Nair, P. Chitosan-hyaluronic acid hydrogel for cartilage repair. Int. J. Biol. Macromol. 2017, 104, 1936-1945. [CrossRef]

150. Almond, A.; Deangelis, P.L.; Blundell, C.D. Hyaluronan: The Local Solution Conformation Determined by NMR and Computer Modeling is Close to a Contracted Left-handed 4-Fold Helix. J. Mol. Biol. 2006, 358, 1256-1269. [CrossRef]

151. Sohrabi, M.; Hesaraki, S.; Kazemzadeh, A.; Alizadeh, M. Development of injectable biocomposites from hyaluronic acid and bioactive glass nano-particles obtained from different sol-gel routes. Mater. Sci. Eng. C 2013, 33, 3730-3744. [CrossRef]

152. Croisier, F.; Jérôme, C. Chitosan-based biomaterials for tissue engineering. Eur. Polym. J. 2013, 49, 780-792. [CrossRef]

153. Bano, I.; Arshad, M.; Yasin, T.; Ghauri, M.A.; Younus, M. Chitosan: A potential biopolymer for wound management. Int. J. Biol. Macromol. 2017, 102, 380-383. [CrossRef] [PubMed]

154. Levengood, S.K.L.; Zhang, M. Chitosan-based scaffolds for bone tissue engineering. J. Mater. Chem. B 2014, 2, 3161. [CrossRef] [PubMed]

155. Nandi, S.K.; Kundu, B.; Basu, D. Protein growth factors loaded highly porous chitosan scaffold: A comparison of bone healing properties. Mater. Sci. Eng. C 2013, 33, 1267-1275. [CrossRef] [PubMed]

156. Chesnutt, B.; Yuan, Y.; Buddington, K.; Haggard, W.; Bumgardner, J. Composite Chitosan = Nano-Hydroxyapatite Scaffolds Induce Osteocalcin Production by Osteoblasts In vitro and Support Bone Formation In vivo. Tissue Eng. A 2009, 15, 2571. [CrossRef] [PubMed]

157. DiMartino, A.; Sittinger, M.; Risbud, M.V. Chitosan: A versatile biopolymer for orthopaedic tissue-engineering. Biomaterials 2005, 26, 5983-5990. [CrossRef]

158. Chen, Y.; Chung, Y.; Wang, L.W.; Chen, K.; Chung, Y.; Wang, L.W.; Chen, K.-T.; Li, S.-Y. Antibacterial properties of chitosan in waterbone pathogen. J. Environ. Sci. Heal. Part A Toxic/Hazard. Subst. Environ. Eng. 2007, 4529, 37-41.

159. Hu, S.G.; Jou, C.H.; Yang, M.C. Protein adsorption, fibroblast activity and antibacterial properties of poly(3-hydroxybutyric acid-co-3-hydroxyvaleric acid) grafted with chitosan and chitooligosaccharide after immobilized with hyaluronic acid. Biomaterials 2003, 24, 2685-2693. [CrossRef] 
160. Vaz, J.M.; Taketa, T.B.; Hernandez-Montelongo, J.; Chevallier, P.; Cotta, M.A.; Mantovani, D.; Beppu, M.M. Antibacterial properties of chitosan-based coatings are affected by spacer-length and molecular weight. Appl. Surf. Sci. 2018, 445, 478-487. [CrossRef]

161. Dotto, G.L.; Campana-Filho, S.P.; Pinto, L.A.A. Chitosan Based Materials and its Applications; Bentham Science Publishers: Sharjah, UAE, 2017; pp. 1-322.

162. Albanna, M.Z.; Bou-akl, T.H.; Blowytsky, O.; Walters, H.L.; Matthew, H.W.T. Chitosan fibers with improved biological and mechanical properties for tissue engineering applications. J. Mech. Behav. Biomed. Mater. 2013, 20, 217-226. [CrossRef]

163. Lee, K.; Jin, G.; Jang, C.H.; Jung, W.; Kim, G. Preparation and characterization of multi-layered poly(3-caprolactone)/chitosan scaffolds fabricated with a combination of melt-plotting/in situ plasma treatment and a coating method for hard tissue regeneration. J. Mater. Chem. B 2013, 1, 5831. [CrossRef]

164. Caridade, S.G.; Merino, E.G.; Alves, N.M.; de Bermudez, V.Z.; Boccaccini, A.R.; Mano, J.F. Chitosan membranes containing micro or nano-size bioactive glass particles: Evolution of biomineralization followed by in situ dynamic mechanical analysis. J. Mech. Behav. Biomed. Mater. 2013, 20, 173-183. [CrossRef] [PubMed]

165. Oliveira, M.B.; Luz, G.M.; Mano, J.F. A combinatorial study of nanocomposite hydrogels: On-chip mechanical/viscoelastic and pre-osteoblast interaction characterization. J. Mater. Chem. B 2014, 2, 5627-5638. [CrossRef] [PubMed]

166. Couto, D.S.; Hong, Z.; Mano, J.F. Development of bioactive and biodegradable chitosan-based injectable systems containing bioactive glass nanoparticles. Acta Biomater. 2009, 5, 115-123. [CrossRef] [PubMed]

167. Yang, J.; Long, T.; He, N.-F.; Guo, Y.-P.; Zhu, Z.-A.; Ke, Q.-F. Fabrication of a chitosan/bioglass three-dimensional porous scaffold for bone tissue engineering applications. J. Mater. Chem. B 2014, 2, 6611-6618. [CrossRef] [PubMed]

168. Cui, X.; Huang, W.; Zhou, J.; Wang, H.; Zhou, N.; Wang, D.; Pan, H.; Rahaman, M.N. Evaluation of an injectable bioactive borate glass cement to heal bone defects in a rabbit femoral condyle model. Mater. Sci. Eng. C 2017, 73, 585-595. [CrossRef]

169. Correia, C.O.; Leite, Á.J.; Mano, J.F. Chitosan/bioactive glass nanoparticles scaffolds with shape memory properties. Carbohydr. Polym. 2015, 123, 39-45. [CrossRef] [PubMed]

170. Mota, J.; Yu, N.; Caridade, S.G.; Luz, G.M.; Gomes, M.E.; Reis, R.L.; Jansen, J.A.; Walboomers, X.F.; Mano, J.F. Chitosan/bioactive glass nanoparticle composite membranes for periodontal regeneration. Acta Biomater. 2012, 8, 4173-4180. [CrossRef] [PubMed]

171. Xianmiao, C.; Yubao, L.; Yi, Z.; Li, Z.; Jidong, L.; Huanan, W. Properties and In vitro biological evaluation of nano-hydroxyapatite/chitosan membranes for bone guided regeneration. Mater. Sci. Eng. C 2009, 29, 29-35. [CrossRef]

172. Bottino, M.C.; Thomas, V.; Janowski, G.M. A novel spatially designed and functionally graded electrospun membrane for periodontal regeneration. Acta Biomater. 2011, 7, 216-224. [CrossRef]

173. Dashnyam, K.; Perez, R.A.; Singh, R.K.; Lee, E.J.; Kim, H.W. Hybrid magnetic scaffolds of gelatin-siloxane incorporated with magnetite nanoparticles effective for bone tissue engineering. RSC Adv. 2014, 4, 40841-40851. [CrossRef]

174. Nardecchia, S.; Carriazo, D.; Ferrer, M.L.; Gutiérrez, M.C.; Del Monte, F. Three dimensional macroporous architectures and aerogels built of carbon nanotubes and/or graphene: Synthesis and applications. Chem. Soc. Rev. 2013, 42, 794-830. [CrossRef] [PubMed]

175. Turnbull, G.; Clarke, J.; Picard, F.; Riches, P.; Jia, L.; Han, F.; Li, B.; Shu, W. 3D bioactive composite scaffolds for bone tissue engineering. Bioact. Mater. 2018, 3, 278-314. [CrossRef] [PubMed]

176. Murphy, C.M.; Haugh, M.G.; O'Brien, F.J. The effect of mean pore size on cell attachment, proliferation and migration in collagen-glycosaminoglycan scaffolds for bone tissue engineering. Biomaterials 2010, 31, 461-466. [CrossRef] [PubMed]

177. Gupte, M.J.; Swanson, W.B.; Hu, J.; Jin, X.; Ma, H.; Zhang, Z.; Liu, Z.; Feng, K.; Feng, G.; Xiao, G.; et al. Pore size directs bone marrow stromal cell fate and tissue regeneration in nanofibrous macroporous scaffolds by mediating vascularization. Acta Biomater. 2018, 82, 1-11. [CrossRef] [PubMed]

178. Valerio, P.; Pereira, M.M.; Goes, A.M.; Leite, M.F. The effect of ionic products from bioactive glass dissolution on osteoblast proliferation and collagen production. Biomaterials 2004, 25, 2941-2948. [CrossRef] [PubMed] 
179. Reffitt, D.M.; Ogston, N.; Jugdaohsingh, R.; Cheung, H.F.J.; Evans, B.A.J.; Thompson, R.P.H.; Powell, J.J.; Hampson, G.N. Orthosilicic acid stimulates collagen type 1 synthesis and osteoblastic differentiation in human osteoblast-like cells in vitro. Bone 2003, 32, 127-135. [CrossRef]

180. Orrenius, S.; Gogvadze, V.; Zhivotovsky, B. Calcium and mitochondria in the regulation of cell death. Biochem. Biophys. Res. Commun. 2015, 460, 72-81. [CrossRef]

181. Kohn, A.D.; Moon, R.T. Wnt and calcium signaling: $\beta$-Catenin-independent pathways. Cell Calcium 2005, 38, 439-446. [CrossRef]

182. Clapham, D. Calcium signaling. Cell 2007, 131, 1047-1058. [CrossRef]

183. Kühl, M. The Wnt/Calcium Pathway. Front. Biosci. 2004, 9, 967-974. [CrossRef]

184. Khoshakhlagh, P.; Rabiee, S.M.; Kiaee, G.; Heidari, P.; Miri, A.K.; Moradi, R.; Moztarzadeh, F.; Ravarian, R. Development and characterization of a bioglass/chitosan composite as an injectable bone substitute. Carbohydr. Polym. 2017, 157, 1261-1271. [CrossRef] [PubMed]

185. Silver, I.A.; Deas, J.; Erecińska, M. Interactions of bioactive glasses with osteoblasts in vitro: Effects of $45 \mathrm{~S} 5$ Bioglass $\left({ }^{\circledR}\right)$, and $58 \mathrm{~S}$ and $77 \mathrm{~S}$ bioactive glasses on metabolism, intracellular ion concentrations and cell viability. Biomaterials 2001, 22, 175-185. [CrossRef]

186. Bonnelye, E.; Chabadel, A.; Saltel, F.; Jurdic, P. Dual effect of strontium ranelate: Stimulation of osteoblast differentiation and inhibition of osteoclast formation and resorption in vitro. Bone 2008, 42, 129-138. [CrossRef]

187. Chattopadhyay, N.; Quinn, S.J.; Kifor, O.; Ye, C.; Brown, E.M. The calcium-sensing receptor (CaR) is involved in strontium ranelate-induced osteoblast proliferation. Biochem. Pharmacol. 2007, 74, 438-447. [CrossRef] [PubMed]

188. Hurtel-lemaire, A.S.; Mentaverri, R.; Caudrillier, A.; Cournarie, F.; Wattel, A.; Kamel, S.; Terwilliger, E.F.; Brown, E.M.; Brazier, M. The Calcium-sensing Receptor Is Involved in Strontium Ranelate-induced Osteoclast Apoptosis. J. Biol. Chem. 2009, 284, 575-584. [CrossRef]

189. Isaac, J.; Nohra, J.; Lao, J.; Jallot, E.; Nedelec, J.M.; Berdal, A.; Sautier, J.-M. Effects of strontium-doped bioactive glass on the differentiation of cultured osteogenic cells. Eur. Cells Mater. 2011, 21, 130-143. [CrossRef]

190. Zhang, W.; Shen, Y.; Pan, H.; Lin, K.; Liu, X.; Darvell, B.W.; Lu, W.W.; Chang, J.; Deng, L.; Wang, D.; et al. Effects of strontium in modified biomaterials. Acta Biomater. 2011, 7, 800-808. [CrossRef]

191. Naruphontjirakul, P.; Porter, A.E.; Jones, J.R. In vitro osteogenesis by intracellular uptake of strontium containing bioactive glass nanoparticles. Acta Biomater. 2018, 66, 67-80. [CrossRef]

192. Yang, F.; Yang, D.; Tu, J.; Zheng, Q.; Cai, L.; Wang, L. Strontium enhances osteogenic differentiation of mesenchymal stem cells and in vivo bone formation by activating Wnt/catenin signaling. Stem Cells 2011, 29, 981-991. [CrossRef]

193. Zhang, Y.; Cui, X.; Zhao, S.; Wang, H.; Rahaman, M.N.; Liu, Z.; Huang, W.; Zhang, C. Evaluation of injectable strontium-containing borate bioactive glass cement with enhanced osteogenic capacity in a critical-sized rabbit femoral condyle defect model. ACS Appl. Mater. Interfaces 2015, 7, 2393-2403. [CrossRef]

194. Lin, K.; Xia, L.; Li, H.; Jiang, X.; Pan, H.; Xu, Y.; Lu, W.W.; Zhang, Z.; Chang, J. Enhanced osteoporotic bone regeneration by strontium-substituted calcium silicate bioactive ceramics. Biomaterials 2013, 34, 10028-10042. [CrossRef] [PubMed]

195. Luz, G.M.; Mano, J.F. Chitosan/bioactive glass nanoparticles composites for biomedical applications. Biomed. Mater. 2012, 7, 054104. [CrossRef] [PubMed]

196. Diba, M.; Goudouri, O.M.; Tapia, F.; Boccaccini, A.R. Magnesium-containing bioactive polycrystalline silicate-based ceramics and glass-ceramics for biomedical applications. Curr. Opin. Solid State Mater. Sci. 2014, 18, 147-167. [CrossRef]

197. Zreiqat, H.; Howlett, C.R.; Zannettino, A.; Evans, P.; Schulze-Tanzil, G.; Knabe, C.; Shakibaei, M. Mechanisms of magnesium-stimulated adhesion of osteoblastic cells to commonly used orthopaedic implants. J. Biomed. Mater. Res. 2002, 62, 175-184. [CrossRef]

198. Sergi, R.; Bellucci, D.; Salvatori, R.; Cannillo, V. Chitosan-Based Bioactive Glass Gauze: Microstructural Properties, In vitro Bioactivity, and Biological Tests. Materials 2020, 13, 2819. [CrossRef]

199. Luz, G.M.; Boesel, L.; Campo, A.; Del Mano, J.F. Micropatterning of bioactive glass nanoparticles on chitosan membranes for spatial controlled biomineralization. Langmuir 2012, 28, 6970-6977. [CrossRef] 
200. Peter, M.; Binulal, N.S.; Soumya, S.; Nair, S.V.; Furuike, T.; Tamura, H.; Jayakumar, R. Nanocomposite scaffolds of bioactive glass ceramic nanoparticles disseminated chitosan matrix for tissue engineering applications. Carbohydr. Polym. 2010, 79, 284-289. [CrossRef]

201. Martins, T.; Oliveira, A.A.R.; Oliveira, A.C.; Boaventura, T.P.; Barrioni, B.R.; Costa-Júnior, E.S.; Pereira, M.M. Novel 3D composites with highly flexible behavior based on chitosan and bioactive glass for biomedical applications. Mater. Chem. Phys. 2017, 189,1-11. [CrossRef]

202. Rinaudo, M. Biomaterials based on a natural polysaccharide: Alginate. (C) TIP Rev. Espec en Ciencias Químico-Biológicas 2014, 17, 92-96.

203. Venkatesan, J.; Bhatnagar, I.; Manivasagan, P.; Kang, K.H.; Kim, S.K. Alginate composites for bone tissue engineering: A review. Int. J. Biol. Macromol. 2015, 72, 269-281. [CrossRef]

204. Rehm, B.H.A.; Moradali, M.F. Alginates and Their Biomedical Applications; Springer: Berlin/Heidelberg, Germany, 2018; Volume 11, pp. 1-268.

205. Pawar, S.N.; Edgar, K.J. Alginate derivatization: A review of chemistry, properties and applications. Biomaterials 2012, 33, 3279-3305. [CrossRef] [PubMed]

206. Lee, K.Y.; Mooney, D.J. Alginate: Properties and biomedical applications. Prog. Polym. Sci. 2012, 37, $106-126$. [CrossRef] [PubMed]

207. Shapiro, L.; Cohen, S. Novel alginate sponges for cell culture and transplantation. Biomaterials 1997, 18, 583-590. [CrossRef]

208. Turco, G.; Marsich, E.; Bellomo, F.; Semeraro, S.; Donati, I.; Brun, F.; Grandolfo, M.; Accardo, A.; Paoletti, S. Alginate/Hydroxyapatite Biocomposite for Bone Ingrowth: A Trabecular Structure with High and Isotropic Connectivity Gianluca. Biomacromolecules 2009, 10, 1575-1583. [CrossRef] [PubMed]

209. Gabbai-Armelin, P.R.; Cardoso, D.A.; Zanotto, E.D.; Peitl, O.; Leeuwenburgh, S.C.G.; Jansen, J.A.; Renno, A.C.M.; van den Beucken, J.J.J.P. Injectable composites based on biosilicate ${ }^{\circledR}$ and alginate: Handling and In vitro characterization. RSC Adv. 2014, 4, 45778-45785. [CrossRef]

210. Park, D.; Choi, B.; Zhu, S.; Huh, J.; Kim, B.; Lee, S. Injectable bone using chitosan-alginate gel/mesenchymal stem cells/BMP-2 composites. J. Cranio Maxillofac. Surg. 2005, 33, 50-54. [CrossRef]

211. Iwasaki, N. Development of cartilage tissue engineering techniques based on biomedical research. Jpn. Orthop. Assoc. 2014, 19, 699-706. [CrossRef]

212. Igarashi, T.; Iwasaki, N.; Kasahara, Y.; Minami, A. A cellular implantation system using an injectable ultra-purified alginate gel for repair of osteochondral defects in a rabbit model. J. Biomed. Mater. Res. Part A 2010, 94, 844-855. [CrossRef]

213. De Long, W.G.; Einhorn, T.A.; Koval, K.; Mckee, M.; Smith, W.; Sanders, R.; Watson, T. Bone Grafts and Bone Graft Substitutes in Orthopaedic Trauma Surgery A Critical Analysis. J. Bone Jt. Surg. 2007, 89, 649-658. [CrossRef]

214. Zeng, Q.; Han, Y.; Li, H.; Chang, J. Bioglass/alginate composite hydrogel beads as cell carriers for bone regeneration. J. Biomed. Mater. Res. Part B Appl. Biomater. 2014, 102, 42-51. [CrossRef]

215. Jell, G.; Notingher, I.; Tsigkou, O.; Notingher, P.; Polak, J.M.; Hench, L.L.; Stevens, M.M. Bioactive glass-induced osteoblast differentiation: A noninvasive spectroscopic study. J. Biomed. Mater. Res. 2008, 86A, 31-40. [CrossRef] [PubMed]

216. Zhao, F.; Zhang, W.; Fu, X.; Xie, W.; Chen, X. Fabrication and characterization of bioactive glass/alginate composite scaffolds by a self-crosslinking processing for bone regeneration. RSC Adv. 2016, 6, 91201-91208. [CrossRef]

217. Srinivasan, S.; Jayasree, R.; Chennazhi, K.P.; Nair, S.V.; Jayakumar, R. Biocompatible alginate/nano bioactive glass ceramic composite scaffolds for periodontal tissue regeneration. Carbohydr. Polym. 2012, 87, 274-283. [CrossRef]

218. Luo, Y.; Wu, C.; Lode, A.; Gelinsky, M. Hierarchical mesoporous bioactive glass/alginate composite scaffolds fabricated by three-dimensional plotting for bone tissue engineering. Biofabrication 2013, 5, 015005. [CrossRef] [PubMed]

219. Luo, G.; Ma, Y.; Cui, X.; Jiang, L.; Wu, M.; Hu, Y.; Luo, Y.; Pan, H.; Ruan, C. 13-93 bioactive glass/alginate composite scaffolds 3D printed under mild conditions for bone regeneration. RSC Adv. 2017, 7, 11880-11889. [CrossRef] 
220. Wu, C.; Ramaswamy, Y.; Zhu, Y.; Zheng, R.; Appleyard, R.; Howard, A.; Zreiqat, H. The effect of mesoporous bioactive glass on the physiochemical, biological and drug-release properties of poly(dl-lactide-co-glycolide) films. Biomaterials 2009, 30, 2199-2208. [CrossRef]

221. Liu, W.; Wang, T.; Yang, C.; Darvell, B.W.; Wu, J.; Lin, K.; Chang, J.; Pan, H.; Lu, W.W. Alkaline biodegradable implants for osteoporotic bone defects-Importance of microenvironment pH. Osteoporos. Int. 2015, 27, 93-104. [CrossRef]

222. Dasgupta, S.; Banerjee, S.S.; Bandyopadhyay, A.; Bose, S. Zn- and Mg-Doped Hydroxyapatite Nanoparticles for Controlled Release of Protein. Langmuir 2010, 26, 4958-4964. [CrossRef]

223. Badr-Mohammadi, M.-R.; Hesaraki, S.; Zamanian, A. Mechanical properties and In vitro cellular behavior of zinc- containing nano-bioactive glass doped biphasic calcium phosphate bone substitutes. J. Mater. Sci. Mater. Med. 2014, 25, 185-197. [CrossRef]

224. Zamani, D.; Moztarzadeh, F.; Bizari, D. Alginate-bioactive glass containing Zn and Mg composite scaffolds for bone tissue engineering. Int. J. Biol. Macromol. 2019, 137, 1256-1267. [CrossRef]

225. Loh, Q.L.; Choong, C. Three-dimensional scaffolds for tissue engineering applications: Role of porosity and pore size. Tissue Eng. Part B Rev. 2013, 19, 485-502. [CrossRef] [PubMed]

226. Jones, J.R. Reprint of: Review of bioactive glass: From Hench to hybrids. Acta Biomater. 2015, 23, S53-S82. [CrossRef] [PubMed]

227. Liu, J.; Rawlinson, S.C.F.; Hill, R.G.; Fortune, F. Strontium-substituted bioactive glasses in vitro osteogenic and antibacterial effects. Dent. Mater. 2016, 32, 412-422. [CrossRef] [PubMed]

228. Reginster, J.; Badurski, J.; Bellamy, N.; Bensen, W.; Chapurlat, R.; Chevalier, X.; Christiansen Genant, H.; Navarro, F.; Nasonov, E.; Sambrook, P.N.; et al. Efficacy and safety of strontium ranelate in the treatment of knee osteoarthritis: Results of a double-blind, randomised placebo-controlled trial. Ann. Rheum. Dis. 2013, 72, 179-186. [CrossRef]

229. Tao, Z.; Zhou, W.; He, X.; Liu, W.; Bai, B.; Zhou, Q.; Huang, Z.-L.; Tu, K.-K.; Li, H.; Sun, T.; et al. comparative study of zinc, magnesium, strontium-incorporated hydroxyapatite-coated titanium implants for osseointegration of osteopenic rats. Mater. Sci. Eng. C 2016, 62, 226-232. [CrossRef]

230. Haider, A.; Waseem, A.; Karpukhina, N.; Mohsin, S. Strontium-and zinc-containing bioactive glass and alginates scaffolds. Bioengineering 2020, 7, 10. [CrossRef]

231. Hatton, J.; Davis, G.R.; Mourad, A.H.I.; Cherupurakal, N.; Hill, R.G.; Mohsin, S. Fabrication of porous bone scaffolds using alginate and bioactive glass. J. Funct. Biomater. 2019, 10, 15. [CrossRef]

232. Wu, C.; Chang, J. Degradation, Bioactivity, and Cytocompatibility of Diopside, Akermanite, and Bredigite Ceramics. J. Biomed. Mater. Res. Part B Appl. Biomater. 2007, 81B, 66-75. [CrossRef]

233. Li, M.; Mondrinos, M.J.; Chen, X.; Gandhi, M.R.; Ko, F.K.; Lelkes, P.I. Elastin Blends for Tissue Engineering Scaffolds. J. Biomed. Mater. Res. Part A 2006, 79, 963-973. [CrossRef]

234. Chakkalakal, D.A.; Mashoof, A.A.; Novak, J.; Strates, B.S.; Mcguire, M.H. Mineralization and pH relationships in healing skeletal defects grafted with demineralized bone matrix. J. Biomed. Mater. Res. 1994, 28, 1439-1443. [CrossRef]

235. Kumar, S. Biocompatible $\beta$-chitin Hydrogel/Nanobioactive Glass Ceramic Nanocomposite Scaffolds for Periodontal Bone Regeneration. Trends Biomater. Artif. Organs 2011, 25, 1-11.

236. Thamaria, N. Synthesis and characterization of alginate scaffolds containing bioactive glass for bone tissue engineering applications. In Proceedings of the 2017 24th National and 2nd International Iranian Conference on Biomedical Engineering, Tehran, Iran, 30 November-1 December 2017; p. 278.

237. Liu, M.; Dai, L.; Shi, H.; Xiong, S.; Zhou, C. In vitro evaluation of alginate/halloysite nanotube composite scaffolds for tissue engineering. Mater. Sci. Eng. C 2015, 49, 700-712. [CrossRef] [PubMed]

238. Yan, J.; Miao, Y.; Tan, H.; Zhou, T.; Ling, Z.; Chen, Y.; Xing, X.; Hu, X. Injectable alginate/hydroxyapatite gel scaffold combined with gelatin microspheres for drug delivery and bone tissue engineering. Mater. Sci. Eng. C 2016, 63, 274-284. [CrossRef] [PubMed]

239. Zmora, S.; Glicklis, R.; Cohen, S. Tailoring the pore architecture in 3-D alginate scaffolds by controlling the freezing regime during fabrication. Biomaterials 2002, 23, 4087-4094. [CrossRef]

240. Mouriño, V.; Newby, P.; Boccaccini, A.R. Preparation and characterization of gallium releasing 3-d alginate coated 45s5 bioglass ${ }^{\circledR}$ based scaffolds for bone tissue engineering. Adv. Eng. Mater. 2010, 12, 283-291. [CrossRef] 
241. Clarkin, O.M.; Wu, B.; Cahill, P.A.; Brougham, D.F.; Banerjee, D.; Brady, S.A.; Fox, E.K.; Lally, C. Novel injectable gallium-based self-setting glass-alginate hydrogel composite for cardiovascular tissue engineering. Carbohydr. Polym. 2019, 217, 152-159. [CrossRef]

242. Brady, S.A.; Fox, E.K.; Lally, C.; Clarkin, O.M. Optimisation of a novel glass-alginate hydrogel for the treatment of intracranial aneurysms. Carbohydr. Polym. 2017, 176, 227-235. [CrossRef]

243. Bériault, R.; Hamel, R.; Chenier, D.; Mailloux, R.J.; Joly, H.; Appanna, V.D. The overexpression of NADPH-producing enzymes counters the oxidative stress evoked by gallium, an iron mimetic. BioMetals 2007, 20, 165-176. [CrossRef]

244. Mourino, V.; Newby, F.; Cattalini, J.; Lucangioli, S.; Boccaccini, A. Physicochemical, biological and drug-release properties of gallium crosslinked alginate/nanoparticulate bioactive glass composite films. Soft Matter 2011, 7, 6705. [CrossRef]

245. Cattalini, J.P.; García, J.; Boccaccini, A.R.; Lucangioli, S.; Mouriño, V. A new calcium releasing nano-composite biomaterial for bone tissue engineering scaffolds. Procedia Eng. 2013, 59, 78-84. [CrossRef]

246. Cattalini, J.P.; Hoppe, A.; Pishbin, F.; Roether, J.; Boccaccini, A.R.; Lucangioli, S.; Mouriño, V. Novel nanocomposite biomaterials with controlled copper/calcium release capability for bone tissue engineering multifunctional scaffolds. J. R. Soc. Interface 2015, 12, 20150509. [CrossRef] [PubMed]

247. Finney, L.; Vogt, S.; Fukai, T.; Glesne, D. Copper and angiogenesis: Unravelling a relationship key to cancer progression. Clin. Exp. Pharmacol. Physiol. 2009, 36, 88-94. [CrossRef] [PubMed]

248. Barralet, J.; Gbureck, U.; Habibovic, P.; Vorndran, E.; Gerard, C.; Doillon, C.J. Angiogenesis in calcium phosphate scaffolds by inorganic copper ion release. Tissue Eng. Part A 2009, 15, 1601-1609. [CrossRef] [PubMed]

249. Gérard, C.; Bordeleau, L.J.; Barralet, J.; Doillon, C.J. The stimulation of angiogenesis and collagen deposition by copper. Biomaterials 2010, 31, 824-831. [CrossRef] [PubMed]

250. Kong, N.; Lin, K.; Li, H.; Chang, J. Synergy effects of copper and silicon ions on stimulation of vascularization by copper-doped calcium silicate. J. Mater. Chem. B 2014, 2, 1100-1110. [CrossRef] [PubMed]

251. Li, S.; Xie, H.; Li, S.; Kang, Y.J. Copper stimulates growth of human umbilical vein endothelial cells in a vascular endothelial growth factor-independent pathway. Exp. Biol. Med. 2012, 237, 77-82. [CrossRef] [PubMed]

252. Mouriño, V.; Cattalini, J.P.; Boccaccini, A.R. Metallic ions as therapeutic agents in tissue engineering scaffolds: An overview of their biological applications and strategies for new developments. J. R. Soc. Interface 2012, 9 , 401-419. [CrossRef]

253. Esteban-Tejeda, L.; Malpartida, F.; Esteban-Cubillo, A.; Pecharromn, C.; Moya, J.S. Antibacterial and antifungal activity of a soda-lime glass containing copper nanoparticles. Nanotechnology 2009, 20, 505701. [CrossRef]

254. Moon, R.J.; Martini, A.; Nairn, J.; Youngblood, J.; Martini, A.; Nairn, J. Cellulose nanomaterials review: Structure, properties and nanocomposites. Chem. Soc. Rev. 2011, 40, 3941-3994. [CrossRef]

255. Wang, X.; Cheng, F.; Liu, J.; Smått, J.H.; Gepperth, D.; Lastusaari, M.; Xu, C.; Hupa, L. Biocomposites of copper-containing mesoporous bioactive glass and nanofibrillated cellulose: Biocompatibility and angiogenic promotion in chronic wound healing application. Acta Biomater. 2016, 46, 286-298. [CrossRef]

256. Ferreira, F.; Souza, L.; Martins, T.; Lopes, J.; Mattos, B.; Mariano, M.; Pinheiro, I.F.; Valverde, T.M.; Livi, S.; Camilli, J.A.; et al. Nanocellulose/bioactive glass cryogels as scaffolds for bone regeneration. Nanoscale 2019, 11, 19842. [CrossRef] [PubMed]

257. Cattini, A.; Latka, L.; Bellucci, D.; Bolelli, G.; Sola, A.; Lusvarghi, L.; Pawlowski, L.; Cannillo, V. Suspension plasma sprayed bioactive glass coatings: Effects of processing on microstructure, mechanical properties and in-vitro behavior. Surface Coat. Technol. 2013, 220, 52-59. [CrossRef]

258. Sergi, R.; Bellucci, D.; Cannillo, V. A comprehensive review of bioactive glass coatings: State of the art, challenges and future perspectives. Coatings 2020, 10, 757. [CrossRef]

259. Chen, Q.; Pe, R.; Munoz, J.; Pe, U.; Larraya, D.; Garmendia, N.; Yao, Q.; Boccaccini, A.R. Cellulose Nanocrystals-Bioactive Glass Hybrid Coating as Bone Substitutes by Electrophoretic Co-deposition: In situ Control of Mineralization of Bioactive Glass and Enhancement of Osteoblastic Performance. ACS Appl. Mater. Interfaces 2015, 7, 24715-24725. [CrossRef] [PubMed] 
260. Chen, Q.; Yang, Y.; Pérez, U.; Larraya, D.; Garmendia, N.; Virtanen, S.; Boccaccini, A.R. Electrophoretic co-deposition of cellulose nanocrystals-45S5 bioactive glass nanocomposite coatings on stainless steel. Appl. Surf. Sci. 2016, 362, 323-328. [CrossRef]

261. Parenteau-Bareil, R.; Gauvin, R.; Berthod, F. Collagen-based biomaterials for tissue engineering applications. Materials 2010, 3, 1863-1887. [CrossRef]

262. Rinaudo, M. Chitin and chitosan: Properties and applications. Prog. Polym. Sci. 2006, 31, 603-632. [CrossRef]

263. Gentleman, E.; Fredholm, Y.C.; Jell, G.; Lotfibakhshaiesh, N.; O’Donnell, M.D.; Hill, R.G.; Stevens, M.M. The effects of strontium-substituted bioactive glasses on osteoblasts and osteoclasts in vitro. Biomaterials 2010, 31, 3949-3956. [CrossRef]

Publisher's Note: MDPI stays neutral with regard to jurisdictional claims in published maps and institutional affiliations.

(C) 2020 by the authors. Licensee MDPI, Basel, Switzerland. This article is an open access article distributed under the terms and conditions of the Creative Commons Attribution (CC BY) license (http://creativecommons.org/licenses/by/4.0/). 